This item was submitted to Loughborough's Research Repository by the author.

Items in Figshare are protected by copyright, with all rights reserved, unless otherwise indicated.

\title{
Radical innovation in family firms: a systematic analysis and research agenda
}

PLEASE CITE THE PUBLISHED VERSION

https://doi.org/10.1108/IJEBR-11-2019-0658

PUBLISHER

Emerald

VERSION

AM (Accepted Manuscript)

\section{PUBLISHER STATEMENT}

This paper was accepted for publication in the journal International Journal of Entrepreneurial Behavior and Research and the definitive published version is available at https://doi.org/10.1108/IJEBR-11-2019-0658.

\section{LICENCE}

CC BY-NC-ND 4.0

\section{REPOSITORY RECORD}

Hu, Qilin, and Mathew Hughes. 2020. "Radical Innovation in Family Firms: A Systematic Analysis and Research Agenda”. Loughborough University. https://hdl.handle.net/2134/11926866.v1. 


\title{
Radical Innovation in Family Firms: A Systematic Analysis and Research Agenda
}

Accepted for publication at International Journal of entrepreneurial Behavior \& Research DOI (10.1108/IJEBR-11-2019-0658) (see www.emeraldinsight.com)

\author{
Qilin Hu (corresponding author) \\ De Montfort University \\ Leicester Castle Business School \\ Leicester LE1 9BH \\ United Kingdom \\ E-mail: qilin.hu@dmu.ac.uk \\ Mathew Hughes \\ Loughborough University \\ School of Business and Economics \\ Loughborough \\ Leicestershire LE11 3TU \\ United Kingdom \\ Tel.: +441509223263 \\ E-mail: m.hughes2@1boro.ac.uk
}

Acknowledgements: We are grateful to the participants of the SIDREA International Workshop on "Family Involvement in Management and firm Growth", Naples, Italy, 8 December 2017, for their helpful comments on the development of this paper. We also thank participants at the IFERA Research Development Workshop, 16-17 March 2017, for their comments and early version of this paper. 


\title{
Radical Innovation in Family Firms: A Systematic Analysis and
}

\section{Research Agenda}

\begin{abstract}
Purpose - Investigation of family firm radical innovation is burgeoning but far less prevalent than studies of family firm innovation in general. Concurrently, studies repeatedly report that family firms exhibit mostly conservative and incremental innovation rather than more radical ones. This is unfortunate because without radical innovation, family firms risk a competency trap in which long-term competitiveness is lost to more innovative rivals. This situation has led to urgent calls among scholars to explicitly acknowledge the heterogeneity of family firm innovation and to understand the conditions for family firm radical innovation.
\end{abstract}

Design/methodology/approach - A systematic review of 51 papers categorized into four scholarly conversations build the foundation for a critical discussion of each line of inquiry. Findings - This study analyzes 51 leading articles and identify four persistent theoretical positions: (1) RBV and capabilities, (2) agency and stewardship, (3) behavioral agency and socioemotional wealth, and (4) the ability and willingness paradox. The authors identify key research problems and research questions needing urgent scholarly and present a framework that captures their complementary and competing assumptions to enable rigorous future research.

Originality/value - To galvanize and spearhead future research efforts, this paper provides a critical analysis of the current understanding of family firm radical innovation with a specific emphasis on the theoretical assumptions at the core of existing investigations and the 8 most important research questions in need of answers.

Keywords - Family firm, radical innovation, family firm innovation, willingness and ability, socioemotional wealth, resources, agency, stewardship, family radical innovation assumptions Paper type - Literature review 


\section{INTRODUCTION}

Innovation is vital to the survival of family firms (Chrisman and Patel, 2012; De Massis et al., 2012; Miller et al., 2015; Sciascia et al., 2015). Without innovation, family firms are at risk of losing competitive advantage, witness their products and services become obsolete, and lose market share to new and existing competitors (Konig et al., 2013). Radical innovation to devise truly new products and services has been described as the "lifeblood of firms" (Slater et al., 2014, p.552). However, family firms often innovate less than traditional firms (Llach and Nordqvist, 2010) because of concerns about wealth preservation (Filser et al., 2018), avoid risk-taking as a route to wealth endangerment (De Massis et al., 2014), have poorly developed innovation capabilities (Sciascia et al., 2015), and exhibit family entrenchment (Anderson and Reeb, 2003) and family orientation lock (Herrero and Hughes, 2019) that diminish the incentive to pursue new innovations (Gast et al., 2018; Kraus et al., 2018). These conditions lead family firms to innovate more incrementally rather than radically (Calabrò et al., 2018; Nieto et al., 2015; Roessl et al., 2010; Wright et al., 2016).

Radical innovations carry significant risk and uncertainties with unpredictable rates of success and acknowledged high failure rates (Barczak et al., 2009; Evanschitsky et al., 2012; Rubera and Kirca, 2012), often unpalatable to family firms. An absence of radical innovation, however, is especially dangerous because it renders the long-term viability of the family firm at risk. Despite a sizeable body of research on family firm innovation in general, only a proportion of studies differentiate by type of innovation and urgent calls have emerged for studies into types of innovation, particularly the conditions for truly novel innovations (Calabrò et al., 2018; De Massis et al., 2015a). This gap in research is of paramount importance. The conditions and skills needed for radical innovation are substantially different to incremental innovation (Bouncken et al., 2018; Dewar and Dutton, 1986; Ettlie et al., 1984; Evanschitsky et al., 2012; Salter et al., 2014). 
Radical innovation is defined as the commercialization of an entirely novel idea, which is new to the markets (Bouncken et al., 2018; Colombo et al., 2017). This type of innovation is substantially different or new technology that represents a clear, risky departure from existing practice, can be disruptive or discontinuous (Bouncken et al., 2018; Garcia and Calantone, 2002), offering potentially higher customer benefits over previous products and services in the industry (Chandy and Tellis, 1998, 2000; Gatignon et al., 2002; Govindarajan et al., 2011; Kyriakopoulos et al., 2016; O’Connor, 1998). Incremental innovation, however, consisting mainly of improvements and line extensions through fitting, recombining, reusing and adopting the existing knowledge (Bouncken et al., 2019; Colombo et al., 2017). Incremental innovation has modest novelty to existing products and services in existing markets carry very little risk to the firm and do not require any substantive transformation in business activity (Ettlie et al., 1984; Garcia and Calantone, 2002; Slater et al., 2014).

Radical innovations require a fundamentally different skillset for a firm than do incremental innovations (Slater et al., 2014). Radical innovations also produce large advancements in price/performance frontiers and can offer unprecedented customer benefits, substantial cost reductions, and firm renewal (Kyriakopoulos et al., 2016; Slater et al., 2014). But, it is precisely these properties that cause unpredictable success rates, high failure rates and modest financial returns (Barczak et al., 2009) that are unpalatable to many family firms (Chrisman and Patel., 2012; Konig et al., 2013). From one perspective, family firm size and resource stocks can determine the firm's capabilities for conducting radical innovation (Habbershon and Williams, 1999; Matzler et al., 2015; Roessl et al., 2010). By contrast, intrafamily conflicts (Block, 2012; Filser et al., 2018), family firm performance (Chrisman and Patel, 2012), and particular preferences and objectives of family members (Anderson and Reeb, 2003; Roessl et al., 2010) can result in risk-aversion (Gomez-Mejia et al., 2007) and short investment horizons (Chrisman and Patel, 2012; Thomsen and Pedersen, 2000), which 
reduce motivation towards radical innovation among family firms (Anderson and Reeb, 2003; Gomez-Mejia et al., 2007). There is heterogeneity in how radical innovation occurs and is implemented among family firms, and family firms themselves are heterogeneous in how they prioritize or create the circumstances for radical innovation. Consequently, the present study examines: (1) what is the current state of understanding of family firm radical innovation; (2) what theoretical lenses are used to examine family firm radical innovation and what are their implications; and (3) what are the key assumptions and questions requiring urgent attention to advance knowledge?

Answers to these questions are essential because to date, studies of family firm radical innovation are far fewer than general studies of family firm innovation (Calabrò et al., 2018; De Massis et al., 2015a). Of the studies specifically speaking to family firm radical innovation, a series of different theoretical lenses are used to frame this activity, creating an array of findings originating from a different set of theoretical assumptions whose implications for the accumulation of knowledge are unclear (Filser et al., 2016). The field lacks an in-depth overview of the growing research effort made towards understanding family firm radical innovation; a detailed evaluation of current academic investigation into family firm radical innovation that identifies inconsistencies, contradictions, and pockets of consensus; a map of the theoretical assumptions associated with each lens and the implications these assumptions hold for the investigation of family firm radical innovation; and ascertains the areas in which future research endeavor should focus for the greatest contribution (Filser et al., 2016; Kraus et al., 2020). This study seeks to address these problems by: (1) assesses the state-of-the-art of knowledge about family firm radical innovation (ascertaining theory, absences, and assumptions), and (2) evaluates the most crucial problems that researchers need to address in their future investigations. Doing so will reconcile the rapid development in theory seen to date and highlight where current 
understanding is at its thinnest and in need of the most urgent attention, both theoretically and empirically.

The present paper builds on 51 leading articles published between 2003 and 2018 in Academy of Management Journal, Administrative Science Quarterly, Entrepreneurship Theory and Practice, International Journal of Entrepreneurial Behavior and Research, Journal of Small Business Management, Family Business Review, Journal of Family Business Strategy, and Journal of Product Innovation Management into family firm radical innovation. Of these 51 articles, 18 directly treat radical innovation in family firms (e.g., Block, 2012; Cassia et al., 2011; Chrisman et al., 2015; De Massis et al., 2012, 2016; Singh and Gaur, 2013; Zahra, 2005) and 33 contribute vital knowledge to the current understanding of the functioning of family firms' radical innovation (e.g., Carney, 2005; Chirico and Salvato, 2014; Gomez-Mejia et al., 2007; Sirmon and Hitt, 2003).

This paper offers two important and timely contributions to the family firm management literature. First, it provides an in-depth overview and point of reference for the burgeoning research effort made towards understanding family firm radical innovation. It crystallizes why family firms have difficulties innovating radically and clarifies the origin of those reasons, critically analyzes the state of current knowledge on those reasons, and identifies high-priority research gaps exist in this debate. Second, it evaluates the current academic investigation of family firm radical innovation, locating and assessing the research advances, contradictions, problems yet to be solved, and promising areas on which to focus future research endeavor for the greatest contribution and impact. In doing so, the authors map the theoretical assumptions associated with each lens and the implications these assumptions have for the investigation of family firm radical innovation. The two contributions of this present study directly respond to very recent petitions by scholars to 
acknowledge and urgently study the heterogeneity of innovation (De Massis et al., 2015a) and with a specific focus on radical innovation (Calabrò et al., 2018).

\section{STRUCTURED LITERATURE REVIEW METHOD}

A structured literature review process and article filtering can be performed through five steps (Mertens, 2005): (1) read articles and define key terms; (2) type the 'keywords' into databases to search and select articles essential to the current research theme; (3) determine the connections among the key terms and discover the similarities and conflicts among them; (4) draw a literature map to link the terms that are relevant to each other; and (5) update the literature map and list of articles, and elaborate the overall review.

The databases identified for this study are ScienceDirect, EBSCO, Springer Link, Wiley, and Sage. The search engines within these databases use Boolean operators to examine their literature portfolio and report their results according to the presence of keywords (Hart, 2004). The results include journal articles, essays, magazines, books and newspapers if there are no criteria to constrain the auto selection. Thus, the universal search criteria applied to these databases to seek articles directly about or providing supporting information about family firm radical innovation were limited to 'English version', 'peer-review', and 'full text' articles. The publication timeframe of the chosen articles was restricted to between 2003 and 2018 in order to show recent advances and establish the crucial assumptions for the future investigation of family firm radical innovation.

To generate a list of articles relevant to the current topic, a priority search process was carried out to cover keywords and related terms found within established definitions of radical innovation (e.g., Chrisman et al., 2015; Ettlie et al., 1984; Garcia and Calantone, 2002; Konig

et al., 2013; Kyriakopoulos et al., 2016; Slater et al., 2014). For instance, 'radical innovation', 'disruptive innovation', 'disruptive technological innovation', 'radical innovativeness' and 
'discontinuous technological innovation' are relevant terms observed as properties of radical innovation (see Garcia and Calantone, 2002) ${ }^{1}$. Extensive keyword searching also prevents important journal articles and scholarly papers from being lost, overlooked or omitted (see Kraus et al., 2020, for an illustration of good practice in the conduct of systematic literature reviews). For example, while searching 'family firms', 'governance', and 'radical innovation', supporting articles such as Carney (2005) will not be revealed among the search results. While inputting 'family governance' and 'competitive advantage' into the search, the seminal paper by Carney (2005) reveals itself in the EBSCO database. Through the initial reading of the articles of Cheng and Van de Ven (1996), Chrisman et al. (2015), Chrisman and Patel (2012), De Massis et al. (2016) and Konig et al. (2013), and a list of search terms and vocabulary was created: 'innovation', 'radical innovation', 'technological innovation', 'family governance structures', 'research and development (R\&D)', 'exploration', 'motivation and ability', 'new product development', 'family influence and firm performance', and 'ownership and control'.

The filtering criteria restricted the search results towards: (1) key academic contributions that have significantly developed the topic and (2) highly relevant articles in line with the current research theme or providing support for radical innovation (e.g., revealing the radical innovation decision process; connecting family governance and radical innovation) (Kraus et al., 2020). These criteria were met in two ways. First, key articles were identified by reviewing the title of the article, the research concept from the abstract, the

\footnotetext{
${ }^{1}$ Radical innovations can possess disruptive properties (Garcia and Calantone, 2002; Slater et al., 2014) but not all disruptive innovations are strictly radical (Smith, 2005; Yu and Hang, 2010). Similarly, Garcia and Calantone (2002) in their review of innovation terminology characterize radical innovation as bearing discontinuous properties, including both market and technology discontinuities. They acknowledge discontinuous innovation as a form of innovation, but in its definition expressly stated that discontinuous innovation, "may be either a radical innovation or really new innovation dependent upon at which level (macro/micro) and which S-curve(s) (marketing/technology/both) is affected by the introduction of the invention to the marketplace" (p.123, emphasis added). Therefore, to ensure that this present study did not omit relevant studies, the authors retained "disruptive" and "discontinuous" as additional of search terms. Thereafter, each paper was screened for its fit to radical innovation.
} 
contents, introduction and conclusion, the key author or authors, the principal argument(s), (un)stated assumptions, research background, and key examples. Second, to support the literature search endeavor, a further selection condition was set by focusing the choice of journals solely on those publication outlets rated highly for journal quality as indicated, for example, by the Association of Business Schools (ABS) (ABS Journal Ranking Guide, 2015) in the UK and relevant, equivalent international systems (e.g., ABCD ratings) (Kraus et al., 2020). While carrying a degree of subjectivity and imprecision attributable to any such ranking of journal quality, this measure helps provide an additional mechanism to reduce the plethora of initial search results into a more manageable quantity based on a generallyaccepted list of journals defined as being of international or world-leading standard (Kraus et al., 2020). Articles were sourced from Academy of Management Journal, Administrative Science Quarterly, Entrepreneurship Theory and Practice, International Journal of Entrepreneurial Behavior and Research, Journal of Small Business Management, Family Business Review, Journal of Family Business Strategy, and Journal of Product Innovation

\section{Management.}

The initial search for radical innovation and family firms meeting these criteria led to 74 papers being retrieved from the aforementioned databases. After a round of screening, 31 papers not explicitly concentrating on radical innovation and family firms were deleted. This screening was completed by examining the title and abstract of each paper. Since few studies discussed family firm radical innovation activities between 1999 and 2003, ultimately, 51 papers published between the start of 2003 and the end of 2018 were selected for final discussion, with 18 articles purely discussing family firm radical innovation and 33 supporting articles relevant to family firm radical innovation.

To analyze these papers, the first step was to categorize them based on the instances of theory used to study the phenomenon of family firm radical innovation. This approach was 
consistent with addressing the research question of the present study. Each paper was screened to ascertain which theoretical perspective was applied. Among the 51 studies that examine radical innovation and family firms, 25 are quantitative, 23 are qualitative, 2 use fuzzy-set qualitative comparative analysis and 1 study employed grounded theory. Two studies used several theories at the same time (Le Breton-Miller et al., 2015, used three theories) and another six used two theories at the same time (Chrisman et al., 2005: Kammerlander and Ganter, 2015; Kellermanns et al., 2012; Konig et al. 2013; Miller et al., 2015; Zahra, 2005). In total, 18 different instances of theory occurred among the 51 studies (see Appendix).

As a second step, the selected scholarly papers about family firm radical innovation grouped naturally into four areas of discussion based on their theoretical perspective: (1) the resource-based view (RBV) and capabilities, (2) agency theory and stewardship theory, (3) behavioral agency theory and SEW, and (4) ability and willingness. In Tables 1 through 4, all the articles are listed together with details of their respective lenses. Some papers are repeated across Tables 1 through 4 because those papers contained more than one theoretical perspective, as described in Step 1. Tables 1 through 4 detail key information about each article under the 4 groups of studies centered on a theoretical perspective. To illustrate this coding procedure, Chrisman et al. (2015) and Veider and Matzler (2016) discuss how conditions pertaining to the ability and willingness of family firms to act influence their innovation activities. Accordingly, these two papers were grouped under 'ability, willingness, and innovation' perspective. Since both papers explained that family involvement in ownership and management will result in different goal selection and idiosyncratic family decision behavior associated with innovation, ability and willingness in this situation belongs to the broader theme of governance as well. As the third step, to identify the factors pertaining to family firm radical innovation in each article, items contained in conceptual models, 
hypotheses or propositions as well as quantitative and qualitative findings were extracted to form the basis for discussion. The synthesis achieved through steps 1 to 3 provided a complete picture of the status of the family firm radical innovation literature, with 4 clusters of studies centered around four theoretical perspectives emerging. As the fourth and final step, these clusters were reviewed and evaluated for their underpinning theoretical assumptions, key findings, and areas of weakness to suggest coherent avenues for future research.

\section{ANALYSIS AND DISCUSSION}

The analysis reveals four dominant theoretical lenses in the study of family firm radical innovation between 2003 and 2018: the RBV and its capabilities extension $(\mathrm{n}=19)$, agency theory and stewardship theory $(n=16)$, behavioral agency theory and SEW $(n=9)$, and the ability and willingness paradox $(\mathrm{n}=7)$.

The analysis is structured as follows: Working through each theoretical lens, this study (1) critically analyzes the state of current understanding, and (2) identifies and extract the essential research problems to set an agenda for future research efforts into family firm radical innovation.

\section{RBV, Capabilities and Family Firm Radical Innovation}

The RBV holds that the stock of valuable, rare, inimitable, and non-substitutable resources that a firm owns can provide it with a sustainable competitive advantage in its competitive market (Barney, 1991). The family firm's resources, namely, internal financing activities, internal and external social capital, and unified ownership and control generate uniqueness that serves as a basis for competitive advantage (Sirmon and Hitt, 2003; Uhlaner et al., 2013).

\section{$\underline{\text { Financial Resources }}$}


Different from non-family firms, financial resources within family firms come mostly from family members (Covin et al., 2016; Sirmon and Hitt, 2003). This type of financial resource has unspecified date of return to the lenders (among the family members) that allows family firms to have longer investment horizon (Sirmon and Hitt, 2003); but it is also limited in its contribution to radical innovation activities which require abundant initial financial resources (Chrisman et al., 2016; Kammerlander and Ganter, 2015). At the same time, the high degree of altruism characterizing family firms' behavior is associated with strategic decisions that generate benefits and interests primarily aligned with the preservation of family members' financial wealth (Miller and Le Breton-Miller, 2005). Although such altruistic behavior can strengthen family bonds and foster loyalty (Miller and Le Breton-Miller, 2005; Nordstorm and Steier, 2015), it also constrains innovation activity because giving out financial benefits to family members reduces the financial resources available for internal investment. This problem is especially acute in family firms at an early stage of the organizational life-cycle (Block, 2012; Cassia et al., 2012; Sharma and Salvato, 2011). When financial resources are lacking, family firms will put greater concern on short-term growth strategies instead of a focus on longer-term innovation or innovation activities (e.g., radical ones) requiring a long-term return horizon (Sharma and Salvato, 2011; Singh and Gaur, 2013).

\section{$\underline{\text { Social Capital }}$}

Social capital includes internal social capital (relationships among employees within the firm) and external capital (relationships between the firm and external entities) (Chirico and Salvato, 2014; Herrero and Hughes, 2019; Hoffman et al., 2006). Family firms normally have a strong bond among employees (both family and non-family employees) (Nordstorm and Steier, 2015). Internally, since family members have shared values and goals, highlycohesive daily operations bearing intense and effective communication are typical (Cassia et 
al., 2011; Hoffman et al., 2006; Nordstorm and Steier, 2015). The communication among family members encourages mutual information sharing, increase the flow of information (Craig and Dibrell, 2006), enhance trust among employees (both family and non-family employees) (Chirico and Salvato, 2014; Nordstorm and Steier, 2015), and facilitate the flow of resources pertinent to family firm performance (Herrero and Hughes, 2019; Mani and Lakhal, 2015). Compared to non-family firms, family firm employees (both family and nonfamily employees) more deeply understand the mission and strategy of the firm (Kor, 2006; Nordstorm and Steier, 2015) and make better use of acquired information in that respect (Patel and Fiet, 2011). Hence, the family firm has the potential to react quickly to opportunities with innovative actions (e.g., increasing investment in R\&D) and tolerate a degree of risk in doing so; this may create advantages for radical innovation activities (Mani and Lakhal, 2015; Zahra, 2003). However, recent studies find that family social capital can be 'too much of a good thing' causing a lock-in that prevents new resources and novel information from entering the family firm (Herrero and Hughes, 2019). Radical innovation activities can prosper within the family firm has a mix of internal and external social capital (Covin et al., 2016).

Externally, family firms search for cooperation with stakeholders, develop long-term attachments with critical stakeholders, and reinforce such partnerships and alliances through generations (Sirmon and Hitt, 2003). Carney (2005) and Dunn (1996) argue that establishing contacts with stakeholders is less of a challenge for family firms as initially speculated because stakeholders are often willing to connect to a family member who owns and manages a business and has a certain social reputation. Connected external stakeholders often prefer to invest in innovation projects that contain benefits from a long-term perspective (Chrisman and Patel, 2012; De Massis et al., 2015b). These external stakeholders contribute an information sharing network that family firms can rely on to acquire new knowledge and business 
opportunities (Mani and Lakhal, 2015; Nordstorm and Steier, 2015). For example, external stakeholders provide wider access to resources such as 'know-how', customer information and market knowledge (Herrero and Hughes, 2019; Kyriakopoulos et al., 2016). New knowledge flows into a firm can stimulate new venture activities (Colombo et al., 2017).

\section{Knowledge Resources}

Knowledge resources are an essential aspect of conducting radical innovation (De Massis et al., 2012; Kotlar et al., 2013; Mani and Lakhal, 2015; Sirmon and Hitt, 2003), and can help family firms maintain their market position and prevent competitors fully imitating a radical innovation (Chirico and Salvato, 2014). A question lies in how family firms acquire and utilize knowledge resources for radical innovation.

The separation of the 'outsider' (non-family employee) and 'insider' (family member) mindset is rooted in many family firms (especially during first and second generations) (Zahra, 2012). Normally, founders favor the development of their children, take extra care with other family members, and eventually undermine non-family employees (Cassia et al., 2011; Zahra et al., 2004). In this case of unequal treatment, family firms can rarely retain nonfamily talent (especially those who hold contradictory opinions to family owners) (Zahra et al., 2004), and, over time, family firms lack a diversification of professional knowledge, generating 'strategic simplicity' (highly routinized operational process knowledge) (Cassia et al., 2012; Miller, 1993). Although family firms are able to generate effective socialization and shape employees towards a common goal, the firms also narrow the innovation paradigm of employees and routinize their operations (De Massis et al., 2015b; Zahra et al., 2004, 2016). Under these circumstances, family firms are expected to increasingly prefer the status quo rather than pursuing radical innovation, learning from experience and utilizing 'ready-made' planning in dealing with problems in the ongoing business environment (Gomez-Mejia et al., 2007; Sharma and Salvato, 2011; Zahra, 2016). As non-family employees' knowledge is less 
efficiently utilized, the knowledge resource for innovation activities depends on the knowledge of founders and other family members (Block, 2012; Miller, 1993).

Family firm founders, who act as CEOs, have the power to integrate various resources and align these resources with family interests to determine strategic actions (Cassia et al., 2011). During the development of the family firm, founders become equipped with vast business experience both in business operation and innovative venturing ( $\mathrm{Li}$ and Daspit, 2016; McConaughy et al., 1998). Yet, Kraizcy et al. (2015) contended that founders are more innovative than managers within a family organization, especially at the early stage of a firm's' life cycle. However, the investment behavior of the founders will not remain constant over the long-term, typically becoming less incentivized to radically innovate at later stages (Craig and Moores, 2006; Hannan and Freeman, 1984; Miller, 1993; Zahra, 2005). Founders concerns to protect family legacy and reputation and preserving family wealth for next generations (Chrisman and Patel, 2012; Schulze et al., 2001) render knowledge resources inert. The narrowing of information search over time exacerbated by low motivation for innovation can impede the inflow of new knowledge (De Massis et al., 2016; Patel and Fiet, 2011). Over time, the ability to conduct innovation further diminishes and is eventually undermined (Zahra, 2005) while commitment to family tradition rises (De Massis et al., 2016).

Learning can reverse this decline, however. The purpose of providing learning for founder-CEOs is to broaden their minds against the narrowing of information search (Hannan and Freeman, 1984; Sorensen and Stuart, 2000; Zahra, 2012), to increase the founder-CEOs' sensitivity to seeking opportunities, and to lengthen founders' investment horizons (Kotlar et al., 2013; Lumpkin et al., 2010). By learning and over time, family founder-CEOs should act less conservatively and develop strategies to access a broader set of resources (Cucculelli et al., 2016; Zahra, 2012). This should result in a higher chance of radical innovation. 


\section{$\underline{\text { Resource-based Questions for Future Research }}$}

Existing studies have emphasized the relationship between family firm resources and radical innovation activities but overlooked the heterogeneity of family firms. Family firms are different from holding different resources, firm sizes and family members' knowledge. These differences may steer family owners' attention towards different innovation activities (Kotlar et al., 2013). For example, the attention or emphasis attributed to risk-aversion in the family firm's decision-making will also reduce when the family firm's financial resources are strong; specifically, an abundance of financial resources can increase the probability of radical innovation activity within family firms (Covin et al., 2016). Considering the size of the family firm, larger firms can have more family social, human, and financial resources than small- or medium-sized firms (Danes et al., 2009), are better placed to internally leverage knowledge and abilities held by family employees, and externally have a better chance to sense opportunities from a relatively strong social capital pool (Chirico and Salvato, 2014). These resources can increase family firms' probability in conducting radical innovation activities; and any negative impact from radical innovation failure can be eased when family firms have slack resources (Gibbert et al., 2007; Xiang et al., 2018). The latter is commensurate with size.

Compared to large family firms, small family firms have less freedom to pursue radical innovation activities. Radical innovation activities require a high degree of sunk costs (once invested, such costs cannot be moved or recovered), and include injections into R\&D (Singh and Gaur, 2013). After new products are launched, the knowledge generated by R\&D might be copied or 'invented around' by rival firms (Harabi, 1995). Consequently, the R\&D investment may not yield or receive the full return initially expected of it (Block, 2012). If family firms consume a lot of resources through innovation activities containing a high risk of failure or long-term payoff, those family firms will likely encounter resource scarcity that makes it hard to maintain daily operations (Singh and Gaur, 2013; Sorensen and Stuart, 2000; 
Xiang et al., 2018). Therefore, family firms may drop into a fluctuated market position judged by the degree of success of innovation activities and exposure to risk (Chrisman et al., 2015). Radical innovation activities cannot entirely depend on the size of the firm either. Although the larger family firm has typically stronger social capital, in which it has a better chance to recognize the opportunities from social networks (Kraiczy et al., 2014), strong social capital can constrain radical innovation because family members will favor dense ties on which they are likely to rely heavily instead of searching for new ties with more novel knowledge (Chirico and Salvato, 2014). In such circumstances, large family firms do not have an absolute higher chance of radical innovation over family firms of small or medium size (Craig et al., 2014). Family firms that are small or medium in size can react to opportunities faster than large firms, because large firms have more formalized bureaucratic systems in which decision-making is systematic in order to meet internal policies and attract legitimacy (Gudmundson et al., 2003; Patel and Fiet, 2011). Concurrently, radical innovation activity forces some parts of the firm to experience intensive change, which can raise family members' fears of losing job control latitudes (Craig and Moores, 2006; De Massis et al., 2016).

Considering the heterogeneity of different family firms, radical innovation is associated with how many degrees of risk, and what types of risk, can trigger family firms to conduct radical innovation (Sciascia et al., 2015; Singh and Gaur, 2013). Ideally, family firms like to engage in innovation activities (e.g. incremental innovation) that generate reliable performance as opposed to simply high performance (Patel and Chrisman, 2014). It seems increasingly necessary to look at the totality of a family firm's resource bundle rather than individual resources. Covin et al. (2016) found that innovation activities are highly related to the 'resource bundle', including a certain market demand from customers, financial resources which can support an overall innovation project, a strong social capital, and firms' knowledge 
which can help exploit innovation and later gain competitive advantage. Also, Mallon et al. (2018) found that the combination of human and financial capital and of human and social capital are crucial for family firms to pursue radical innovation. However, there is no causal relationship between each resource within a resource bundle and radical innovation (Covin et al., 2016; Mallon et al., 2018). That is, family firms appear to rely on unique resource bundles as the underlying condition for radical innovation; but the composition and confirmation of these bundles remains unknown.

\section{[INSERT TABLE 1 ABOUT HERE]}

The analysis of family firm radical innovation studies through the lens of the RBV and capabilities (Table 1) reveals that current investigations are limited in their treatment and assessment of the bundling together of possible resources held by a family firm to cause and commercialize radical innovation activities. That is, family firms having abundant resources should experience fewer uncertainties in pursuing radical innovation than rival firms lacking in well-developed resources; but ownership alone does not explain the extent to which innovation activity occurs (e.g., Kyriakopoulos et al., 2016). Instead, understanding the conditions that steer resource allocation is necessary to understand rent generation.

Correcting this error is beneficial to make a contribution to understanding family heterogeneity and radical innovation from a resource perspective. A further unresolved problem, however, is about what resource stocks and bundles should consist of and whether specific resource histories and trajectories create lock-ins that further hinder family firm radical innovation. This requires a shift in theoretical assumptions set around the ownership of resources and towards the composition of the resources held or accessible by the family firm.

Research question 1: What resource bundles should family firms possess or develop to facilitate radical innovation? Are there specific resource histories and trajectories that create facilitate or hinder the family firm in terms of radical innovation activities? 
As reported in Table 1, the learning process of founders and next-generation leaders can fail to achieve radical innovation activity if they have low individual absorptive capacity if the process from receiving new knowledge to utilizing it in a radical innovation is slow (Huang et al., 2015). Meanwhile, knowledge accumulation is a slow and costly process in which firms will continuously inject time and money before witnessing a radical innovation (Patel and Fiet, 2011). While studies converge on the need for absorptive capacity to support family firm radical innovation, an understanding of what kind and degree of knowledge family founders, owner-managers or second-generation leaders should possess to help their firms conduct radical innovation is missing. This requires a shift from theoretical assumptions to do with learning as a process towards granular analysis of knowledge content which focuses on the boundary conditions of the knowledge held, owned or accessed by family managers and how these restrict or increase the aggregate flow of knowledge to radical innovation.

Research question 2: What kind and degree of knowledge should the family founder(s), owner-manager(s), or next-generation leader(s) possess, acquire or seek to build within the family firm to change the system of constraints in favor of radical innovation?

\section{Agency Theory, Stewardship Theory and Radical Innovation}

The unification of management and control in the family firm can set much closer alignment between the agent manager and owner, reducing traditional agency costs and conflicts between owners and managers (Block, 2012; Filser et al., 2018; Le Breton-Miller et al., 2015). Unlike non-family firms, the family owner normally has great power to control the firm and take decisions, and high family involvement in management can generate effective monitoring to minimize agency cost (Chen and Hsu, 2009; Zahra, 2005). Some scholars reason that there is a positive relationship between family involvement in ownership and propensity to pursue radical innovation activities (Block, 2012; Zahra, 2005; Kellermanns et 
al., 2012; Le Breton-Miller et al., 2015; Singh and Gaur, 2013). However, a negative relationship between family involvement in ownership and degree of innovation is also believed to exist (Chen and Hsu, 2009; Matzler et al., 2015). The two different positions depend on specific theoretical assumptions that cause one set of predictions to take precedence over the other. But, this difference might also be due to overlooking how a variety of actors configure innovation in family firms (Hughes et al., 2018).

Carney (2005) proposes that family involvement generates three main governance propensities: parsimony, personalism, and particularism. Under parsimony, family managers preserve resources and allocate them carefully. Firms reduce their risk-taking activities and pool their resources for current survival and future development. Personalism refers to the family firm having concentrated management and ownership, granting great power for family members. Strategic decision-making and problem solving can then circumvent bureaucratic control within these firms. Based on personalism, particularism represents strategic decisions being influenced by non-economic family goals. For instance, family owner-managers consider non-financial benefits (e.g. ownership) of others while making a strategic decision (altruism) (Chrisman et al., 2005; Chrisman et al., 2012).

In terms of firm survival, Carney (2005) found that the three governance propensities can generate distinctive activities for gaining competitive advantage. Parsimony propensity can help pool financial and human resources to outcompete other rivals in environments in which resources are scarce (Sirmon and Hitt, 2003); while the combination of personalism and particularism can accumulate social capital (e.g. kinship, ethnicity group, community and political affiliation) for long-term development (Miller and Le Breton-Miller, 2003), and can imbue family members with the power to make quick decisions in reacting to opportunities.

However, the propensity of parsimony, personalism, and particularism can also influence radical innovation in different ways. Under parsimony, family firms will primarily 
concentrate on wealth preservation and cost-saving instead of innovative venturing while dealing with the risk of market resource scarcity (De Massis et al., 2015b; Sirmon and Hitt, 2003). Since radical innovation requires various resources, the large sunk costs demotivate family owners from making investments if the next innovation activities also include high uncertainties (Singh and Gaur, 2013). In order to shift the owner's willingness towards innovation projects, agent managers, in the case of the parsimonious propensity, make investments in innovation activities exhibiting low levels of uncertainty; that is, those investments that can increase sales quickly with a short return period, instead of conducting a project which contains short-term losses but long-time horizon for returns even if such projects seem promising (Sharma and Salvato, 2011; Singh and Gaur, 2013).

Under personalism and particularism, although the high involvement of family members can provide owner-managers with high power, the decision-making is likely to be highly limited to altruistic behaviors in which only innovation activity that can demonstrably benefit most family members (both current generation and next generation) will most likely be chosen (Berrone et al., 2012; Chrisman et al., 2012; De Massis et al., 2015b). Family involvement can reduce agency cost by reducing the need for monitoring, but the tendency towards high altruism behavior (e.g. nepotistic appointments) and managerial entrenchment can attract family free-riders (who have high dividends but are not engaging in the business) and provide power for family members to pursue self-interests (Block, 2012; Chrisman et al., 2005), which can a cause misuse of funds in radical innovation projects, and eventually cause agency problems again (Chen and Hsu, 2009). High family involvement can also render severe conflicts that adversely impact firm performance (Faccio et al., 2001; Filser et al., 2018).

[INSERT TABLE 2 ABOUT HERE] 
Analyzing the arguments through the lens of agency theory (Table 2), the degree of risk-aversion is highly related to the different degrees of family involvement in ownership and management, and styles of governance (Chrisman et al., 2012; Fernandez and Nieto, 2006; Le Breton-Miller et al., 2015). With a high degree of family ownership and the parsimonious propensity, firms are less likely to innovate radically because high ownership creates a tight organizational control focused on the goal of wealth preservation. These conditions can further shape employees' ideas and behaviors towards a conservative trajectory and impede innovative thinking over time (Cheng and Van de Ven, 1996; Munari et al., 2010).

Nevertheless, a counter set of theoretical assumptions exists. Under personalism, particularism and a high family ownership context, although altruism limits the behavior of family firms, opportunistic investment decisions are encouraged if the proposed investment aligns with the interests of family members (e.g. long-term profitability and survival) (Block, 2012; De Massis et al., 2012; Zahra, 2005). A family firm would likely engage with radical innovation because of the potential for great long-term benefits in line with such goals, even though radical innovation may put short-term wealth at risk (Chrisman et al., 2012). In this case, the risk-aversion behavior normally expected of family firms can be reduced when family firms focus on long-term potential. This theoretical assumption is consistent with ideas of patient capital. However, there is little research classifying levels of family involvement in ownership and management that would generate different levels of risk-taking behavior under personalism and particularism, nor is there sufficient research that identities why one family firm would adopt the long view over and above the short view despite both reflecting some combination of parsimony, personalism and particularism tendencies.

Research question 3: Under what conditions does a family unit treat a radical innovation project as being in line with the interests of family members? What family properties encourage radical innovation as opposed to more conservative courses of actions? 
Stewardship theory provides an alternative viewpoint to the agent-principal relationship and instead sees family members as custodians of the business and stewards of its long-term health: rather than concerns over self-interest, family members will act altruistically as stewards of the business and act in the collective interests of the family and the family business (Davis et al., 1997; Miller and Le Breton-Miller, 2006). Family members, with stewardship thinking, are highly committed to the firm's mission (Zhang et al., 2018) and have a high level of mutual trust among themselves (Eddleston and Kellermanns, 2007). Thus, stewardship thinking has the potential to shift family members' attention away from nepotism, personal gain, and the expropriation of firm resources, and towards a collective benefit to the firm and the family (Eddleston et al., 2008; Kellermanns et al., 2012). Consequently, family members as stewards may prioritize the long-term wealth and survival of the business, for which radical innovation activities are vital.

Stewardship behavior is motivated by reciprocity induced by the strength of altruism and the existence of robust family bonds (Eddleston and Kellermanns, 2007; Kellermanns et al., 2012). A greater degree of stewardship is expected when more family members are involved in the family firm (Corbetta and Salvato, 2004; Miller et al., 2007). Ashwin et al. (2015) found that family involvement is positively related to R\&D expenditure (as an important antecedent of radical innovation) when stewardship behavior is high within a family firm. However, family involvement has the potential to increase the degree of ownership dispersion, through which ownership control is taken by greater numbers of family members, thereby diluting the control of any one family member or group (Kellermanns et al., 2008; Kellermanns et al., 2012). When ownership dispersion is high, conflicts among family members in relation to money, managerial roles, decision rights and control latitudes will return to the family firm (Kellermanns et al., 2012). Under such circumstances, the benefits of stewardship give way to the return of agency problems. Increases in agency issues (e.g. self- 
serving individuals acting in pursuit of personal goals) and a commensurate reduction in stewardship behaviors impede family firm radical innovation. Identifying ways to maintain a consistent level of stewardship thinking is potentially crucial for family firm radical innovation. One solution may lie in the composition of family goals, clarity over goal setting, and goal congruence among individual family members. Goal incongruence has the potential to increase destructive conflict that reduces stewardship and increases an agency mindset.

Further competing findings are also found among previous studies using stewardship theory. From one perspective, studies believe that stewards are intrinsically motivated to maintain business control for next-generation leaders (Miller and Le Breton-Miller, 2005). Maintaining business control indicates the firm's intention to extend business continuity to appropriate longer-term benefits (Ashwin et al., 2015). As stewardship behavior increases during such a period, family members prefer to work closely together and the subsequent collaboration, trust, constructive conflict, and knowledge sharing can facilitate radical innovation behavior (Eddleston and Kellermanns, 2007; Miller et al., 2008). However, studies also report that family firms are less involved in radical innovation activities (e.g., R\&D expenditure) when family owners are concerned with maintaining control for next-generation leaders (Chen and Hsu, 2009; Huybrechts et al., 2013). Family owners' intention to safeguard the business for future generations decreases owners' disposition to take risks in favor of reinforcing the status quo and maintaining business stability (Huybrechts et al., 2013). These competing findings question the feasibility of the relationship between stewardship behavior and family firm radical innovation. Although stewardship behavior has potential to facilitate radical innovation behavior, pursuing radical innovation is dependent on the decisions of family owners. Therefore, the promise of stewardship for family firm radical innovation is undecided and remains an enduring conundrum. The solution to this conundrum appears to lie in understanding the differences between constructive and destructive conflict among the 
goals of family members, understanding the circumstances for productive versus unproductive stewardship, and what governance conditions may propagate productive stewardship over individual agency.

Research question 4: How do family firms foster and maintain stewardship thinking among family members to support family firm radical innovation activities? In what ways do family firms foster stewardship behavior to support family firm radical innovation while preserving control for next-generation leaders?

\section{Behavioral Agency, SEW and Radical Innovation}

Behavioral agency theory entails that risk-bearing decision attitudes are context dependent (Kahneman and Tversky, 1979). For instance, by combining resources, agency theory and radical innovation, family owners would pay considerable attention to avoid risk-taking, or at the very least calculating the risks of an innovation project in order to prevent the loss of wealth (Sciascia et al., 2015; Miller et al., 2015). This loss of wealth includes financial wealth and socioemotional wealth (SEW) (Gomez-Mejia et al., 2007). To this end, the decisionmaking of family firms is typically more about loss-aversion than risk-aversion in terms of avoiding losses (particularly to SEW) than with obtaining gains. For example, Gomez-Mejia et al. (2007) argued that when faced with a risk to financial and non-financial wealth (SEW), the family firm is willing to tolerate an economic loss (or hazard) to protect its SEW.

SEW endowment represents the non-financial wealth of the family and includes the preservation of family reputation and social identity, social capital, the degree of family influence (control), and the longevity of the business through generations (Gomez-Mejia et al., 2007). Family firms protect their family legacy and avoid pursuing the type of innovation that has a strong tendency to harm such a legacy (De Massis et al., 2016); but, family firms can sometimes engage in innovation for the sake of gaining long-term benefits without losing family control (Miller and Le Breton-Miller, 2005). Compared to financial wealth, family 
firms typically give stronger attention to SEW endowment and attach greater importance to it. Doing so results in three decision behaviors with regard to risk-taking.

First, according to Berrone et al. (2010), family firms have the intention to preserve SEW endowment, even if such conservation intention will miss financial opportunities. In this regard, family firms seldom conduct radical innovation because it might create changes that endanger the SEW endowment (e.g. social identity, ownership and control, and continuity of business) (Berrone et al., 2012; Morck and Yeung, 2003; Le Breton-Miller et al., 2015). Second, the preference family firms attach to risk-taking may increase when firm performance is in decline and likely to harm SEW if left to continue (Berrone et al., 2012; Gomez-Mejia et al., 2007). In order to rescue losses in SEW endowment caused by poor firm performance, family firms can act more innovatively than before. In this case, innovation activities would be considered as a strategy for the purpose of saving SEW. However, theoretically, it implies that such a risk-tolerant strategy will not be pursued until firm performance has reached a point where SEW itself is also decreasing (Sciascia et al., 2015). Third, although Chrisman and Patel (2012) argued that family firms could emphasize entrepreneurial behavior, particularly when concerned about passing the business on to next-generation family members (because renewal of the family business can provide career opportunities for next generations) (Chrisman and Patel, 2012; Kammerlander and Ganter, 2015), considering that such renewal process would be conducted under the premise of identity and reputation protection (Berrone et al., 2010), incremental innovation is more likely to be adopted as a renewal strategy than radical innovation (Chrisman and Patel, 2012).

Kraiczy et al. (2014) and Sciascia et al. (2015) argued that risk-taking and risk-averse behavior within family firms should be dependent on the weighting placed on pursuing either short-term or long-term goals. Short-term goals are specific, precise and practical and deal with improving the current business (Chrisman and Patel, 2012). When family firms put a 
heavier weight on pursuing short-term goals than long-term goals, family members prioritize short-term investment to maintain/enhance current SEW endowment and receive a quick return such as short-term sales growth (Kammerlander and Ganter, 2015; Miller et al., 2015). In this case, incremental innovation is prioritized in daily operations (Kraiczy et al., 2014; Sharma and Salvato, 2011). By contrast, long-term goals are generated from the combination of the firm's current performance, capability, business environment and its future business aims (Cucculelli et al., 2016). Long-term goals are fuzzy and uncertain, containing not only risks but the potential for the firm's long-term development and survival (Le Mens et al., 2015). Since long-term goals are distant from the current business aim, if family members have the intention to pursue long-term goals instead of short-term goals, family firms are likely to act radically in strategic decision-making and choose radical innovation as an option to assist in achieving long-term goals (Cucculelli et al., 2016; Miller et al., 2015). Thus, family firms have shown willingness to take short-term losses of both economic wealth and SEW, with less emphasis on altruistic behavior, and hire non-family talent (Chrisman and Patel., 2012; Sciascia et al., 2015), in contrast to what the authors might expect from a pure SEW perspective (e.g., Berrone et al., 2010; Kammerlander and Ganter, 2015).

In an investigation of family manufacturing firms, Chrisman and Patel (2012) suggest that the investment horizon can be shifted from short-term to long-term within family firms. Family CEOs like to calculate the potential losses and gains of wealth before investing in R\&D and to assess R\&D performance frequently after the investment. For example, when uncertainties of conducting innovation have exceeded family CEOs' perception of acceptable risk, family CEOs hesitate to make a risky decision in responding to the innovation (Cucculelli et al., 2016; Kammerlander and Ganter, 2015; Kraziczy et al., 2014). However, if the R\&D performance has met the perception of family owners in terms of increasing economic performance, at the same time maintaining or enhancing the SEW endowment, 
family owners become more risk-willing to make fuzzier and longer-term investment which contains more uncertainties (Chrisman et al., 2012; Li and Daspit, 2016). In this case, innovation activities start from incremental ones including a low degree of risk and uncertainty and move towards radical innovation (Kraiczy et al., 2014; Li and Daspit, 2016). In turn, the investment horizon becomes increasingly concentrated on the long term.

When family firms have engaged in long-term investment, and the actual R\&D performance at the current stage is lower than the performance aspirations in economic and non-economic wealth terms, family firms suspect the current R\&D might cause further losses of financial and SEW wealth, and invest more in R\&D in order to receive better R\&D performance in the future (Chrisman and Patel, 2012). Through such a mechanism of investing in $R \& D$ in the long-term, family firms have a better chance to conduct radical innovation through the accumulation of learning and experiencing R\&D.

\section{[INSERT TABLE 3 ABOUT HERE]}

Through the lens of behavioral agency theory and SEW (see Table 3) then, a question can be asked, 'does maintaining SEW always conflict with the decision to take risks?' The majority of theoretical assumptions suggest so: family firms gradually take hold of SEW endowment while family involvement is increasing (Berrone et al., 2012) and family firms act in progressively more risk-averse ways. However, studies have found a positive relationship between family involvement and entrepreneurial behavior (De Massis et al., 2014; Konig et al., 2012). Family involvement can enhance family members' power in allocating human capital, social capital and financial capital towards R\&D investment (De Massis et al., 2012). At the same time, increasing numbers of family members, involving a larger number of generations, can broaden the firm's knowledge in sensing business opportunities (Kraiczy et al., 2014). In this case of family involvement, family firms increasingly take hold of SEW endowment but at the same time enhance risk-taking behavior. 
Gomez-Mejia et al. (2007) suggested that risk-taking or risk-willing decision behavior should depend on the maintenance of SEW endowment and rescuing the loss of SEW endowment, respectively. SEW entails five dimensions, namely: family control and influence, identification of family members with the firm, binding social ties, emotional attachment of family members, and the renewal of family bonds to the firm through dynamic succession (Berrone et al., 2012). The contradictory findings and associated theoretical positions revealed above can potentially be explained by discovering which dimension of SEW is the current priority for the current strategies of family firms. For example, Brinkerink and Bammens (2018), and Kammerlander and Ganter (2015) both found that there are different aspects of noneconomic goals which can lead to different decision behaviors within family firms. This may explain how, from a relatively stable set of theoretical assumptions within behavioral agency theory and SEW theory, very different behaviors are observed empirically by family firms. These theories may be advanced through a more granular analysis of SEW to understand how specific aspects of SEW might lead to alternative predictions about family firm radical innovation. SEW has been used to make general predictions about family firm radical innovation; but this aggregate and rather blunt use of the theoretical instrument is not consistent with observations from practice and findings from empirical studies.

Decision behavior might further differ based on dimensions of family identity, family control and transgenerational value (Brinkerink and Bammens, 2018; Chrisman and Patel, 2012). According to Brinkerink and Bammens (2018) and, Chrisman et al. (2015), family firms shift from risk-averse towards risk-willing behavior when the family is currently concentrating on maintaining transgenerational value in the future. Family firms that strive for intrafamily succession conduct radical innovation in order to increase transgenerational control (Berrone et al., 2012; Chrisman et al., 2015). Thus, contingent factors may drive family firms to either place more weight on maintaining transgenerational control than 
maintaining the identity of family firms or vice versa. Thus, family firms are risk-averse or risk-willing even when they share the same purpose of maintaining SEW endowment.

Research question 5: Can a multi-dimensional conceptualization of SEW both support and dilute radical innovation? Does a dimensional conceptualization of SEW carry greater predictive accuracy than a unidimensional conceptualization?

\section{Ability and Willingness Paradox, and Radical Innovation}

The ability and willingness view of family firm innovation grew out of the behavioral agency and SEW theories, however, it has since developed to exhibit its own specific properties and set of assumptions about the occurrence (or not) of family firm innovation activity. Existing studies on this subject are reported in Table 4. Ability is the discretion of family members to manage family firms' resources in a strategic direction, and the capability (combination of financial resources, human resources, social capital, and firms' knowledge and experience) of family firms allows them to pursue the strategic direction in question (De Massis et al., 2014; Cucculelli et al., 2016). Willingness relates to family owners' goals, intentions and motivation, which can drive them to behave in a particular way (Chrisman et al., 2015).

Miller et al. (2015) contended that SEW dimensions could impact on innovative goal construction and identified two extremes of SEW objectives in line with the decision behavior of family firms. The first extreme is 'feeding parochial family desires (FPFD)'. Under this specific SEW objective, family firms act conservatively focusing on parochial family interests and in turn create a risk-averse organizational decision-making culture. Such risk-averse behavior can decrease the investment in radical innovation activities and in turn block family firms' ability to innovate through generations. Second, the other extreme of SEW is 'creating an evergreen organization (CAEO)' in which family firms act proactively in innovation by 
continuously investing in stakeholders, human capital, and social capital. The vision of this evergreen family firm type is to establish a robust business.

\section{[INSERT TABLE 4 ABOUT HERE]}

SEW dimensions may shift across conservative behavior and innovative behavior. If SEW dimensions can drive family firms' willingness to start acquiring resources to innovate (Brinkerink and Bammens, 2018; Cucculelli et al., 2016; Veider and Matzler, 2016), they may pursue radical innovation more when SEW has reached the CAEO extreme. The research problem here is what factors drive SEW to shift towards a CAEO extreme and in turn increase the willingness to pursue radical innovation and construct relevant, innovative goals (Cucculelli et al., 2016; Veider and Matzler, 2016).

Research question 6: What factors drive family SEW towards the CAEO dimension, increase willingness to pursue radical innovation and construct relevant, innovative goals?

The business environment plays a pivotal role in strategic decision-making. Strategic goals are set after analyzing the environment for demand, market competition and consumer tastes (Le Mens et al., 2015). A volatile environment with unstable demand, strong market competition and frequent change in consumer tastes pressurizes family CEOs to rethink current and long-term strategic goals (Ingram et al., 2014; Prajogo, 2016; Venkatraman and Camillus, 1984). Both family firms and non-family firms share two aspects of adaptive behavior: firms create strategy to fit the current business environment and diversify their capabilities to fit environmental changes (Venkatraman and Camillus, 1984).

In a low dynamic business environment, the future will be similar to the present (Hamel, 1996; Hannan and Freeman, 1978). Changes are slow and predictable. In such a context, competitive advantage is acquired by diversifying products and services and differentiating from rivals (Sharma and Salvato, 2011; Zahra, 2018). Family firms can 
implement incremental innovation to maintain fitness with the environment. Theoretically, as long as family firms are constantly creating strategic fitness, they can prevent obsolescence (where new products will supersede and replace existing ones in the business market in time) (Hannan and Freeman, 1977; Venkatraman and Camillus, 1984; Zahra, 2018). In a low dynamic environmental context, radical innovation is not urgent for business development. When radical product innovation delivered to the market, consumers will have little knowledge and experience when facing these new products (Le Mens et al., 2015). It will take a longer period for consumers to understand new products under these conditions (Prajogo, 2016). Since radical product innovation could ruin the identity of the firm (a dimension of SEW) within consumers' minds, they will question the reliability and capability of family firms to provide products that compete with the top performers at a similar price level (Sorenson and Stuart, 2000). Consumers will hesitate to choose the new products and sales will almost certainly fall (Le Mens et al., 2015). Although radical innovation might be promising in the future, family firms need to withstand an extended period of low or no sales profits until such time that consumers have realized the new products are better than the current ones and switch to those new products (Prajogo, 2016). Therefore, low environmental dynamism would decrease CAEO intensity and increase FPFD intensity that decreases the willingness to allocate resources towards radical innovation.

When family firms operate in a highly dynamic environment with high turbulence and uncertainty, the tastes of consumers change quickly such that mere continuous improvements are unlikely to be enough to track environmental changes. But, because the taste of consumers is frequently changing, this situation can create a number of niches within the market (Prajogo, 2016). These niches can provide family firms with opportunities to implement radical innovation, which can motivate family firms to act radically and keep generating new products to attract consumers' attention (Craig and Moore, 2006; Venkatraman and Camillus, 
1984). CAEO can increasingly take hold and drive family firms to invest more intensively in R\&D. Because the tastes of consumers are frequently changing and old-fashioned products become outdated quickly, it is difficult for family firms to survive if they have little intention to pursue radical innovation. In order to increase survivability and create strategic fit, family firms would be expected to decrease FPFD intensity and engage in more radical innovation.

Research question 7: How does environmental dynamism alter the relationship between

(a) CAEO intensity and degree of pursuit of radical innovation and (b) the relationship between FPFD intensity and degree of pursuit of radical innovation within family firms?

\section{Innovation beyond the Boundaries of the Family Firm}

The ability and willingness of family owners and managers to direct organizational resources towards radical innovation activity is traditionally assumed to be driven by the interests and unique power afforded by the familial character. However, alternative forms of governance that involve outsiders (e.g., trusts) can destabilize the freedom of the family to act opportunistically or with impunity (Scholes and Wilson, 2014). Trustees, for example, can alter the control rights of family owners to add, direct, or dispose of the firm's assets, which, in turn, can affect their willingness and ability to engage in entrepreneurship and innovation activity (Wright et al., 2016).

Historically, research on family firm radical innovation has looked inside the family firm for innovation. This is understandable because family firms are control-oriented, prioritize the preservation of SEW, and are reluctant to form new relationships with outsiders or involve them directly in strategic activity (e.g., Cesinger et al., 2016). However, the phenomenon of open innovation suggests there are many opportunities to source radical innovations from outside the firm's boundaries. So far, family firms do not show the same inclination to engage in open innovation compared to non-family firms. Their desire to 
preserve control over innovation (Kotlar et al., 2013) is juxtaposed against emerging findings that they are well-placed to appropriate external knowledge (Patel and Fiet, 2011).

Collaborative innovation (Feranita et al., 2017) and open innovation (Röd, 2016) holds promise to resolve the innovation dilemma in family firms.

Research question 8: What are the conditions that favor family firm radical innovation through collaborative or open means?

\section{CONCLUSIONS AND FUTURE RESEARCH AGENDA}

\section{[INSERT FIGURE 1 ABOUT HERE]}

Family firm scholars have made considerable advances in understanding family firm innovation. But, family firm radical innovation as a specific type of innovation is very different to other forms of innovation such as incremental innovation. Crucially, studies repeatedly report that the majority of family firm innovation is incremental (Hall et al., 2001; Nieto et al., 2015; Wright et al., 2016). Radical innovations are fundamentally different to incremental innovations, requiring different skillsets, conditions and capabilities.

Consequently, it cannot be assumed that conditions favorable for innovation in general are sufficient to enable this crucial type of innovation. Without radical innovation, family firms are in jeopardy to competitors and failure the long term.

Research into family firm radical innovation is burgeoning, yet, there remains no critical analysis and evaluation of family firm radical innovation, until now. The intention of this paper was to evaluate the current understanding of radical innovation among family firms to determine the theories have been used to predict and explain radical innovation activity in family firms, and distil their underpinning theoretical assumptions to identify research questions in need of urgent enquiry to build the knowledge of family firm radical innovation. 
After systematically analyzing and evaluating 51 leading papers published between 2003 and 2018 relevant to family firm radical innovation, these studies consistently fall under four theoretical lenses: RBV and capabilities, agency theory and stewardship theory, behavioral agency theory and SEW, and ability and willingness. RBV and agency theory studies have dominated the last decade, while behavioral agency theory and SEW, and the ability and willingness paradox, have grown substantively in use between 2007 and 2012. The consistent argument about family firm radical innovation among the four lenses lies in the alignment of family involvement in ownership and management, resources, governance and goal setting. That is, if family firms have a long-term investment horizon and the proposed radical innovation is in line with its goals and strategies, they will exhibit higher willingness to devote internal financing resources (e.g. acquiring financial support from family members), R\&D investment, and knowledge acquisition and renewal efforts towards radical innovation. But this motivation relies on the ability to innovate while being largely dictated by the accumulation of resources over time so long as the agency and behavioral conditions in the firm support resource allocation towards radical innovation activities.

At this point, it is apparent that the theoretical lenses are not distinct in their observations about family firm radical innovation and their point of convergence is largely to do with ideas of willingness and ability to innovate. However, this is an oversimplification and such a synthesis masks that each theory approaches the problem of family firm radical innovation with a different set of theoretical assumptions, some of which compete across each other and within each other. These theoretical assumptions and their differences are exposed in Figure 1. For example, under the RBV and capabilities, it is expected that high family firm idiosyncratic resources may support the propensity for pursuing radical innovation, not least because increased resource stocks support the ability to innovate (assumption A1). However, a competing assumption is that the stronger the tradition of the family firm (itself a resource), 
the stronger the propensity for radical innovation because of the inertia brought on by tradition (assumption A2). Moreover, assumptions about resources (A1-3) and agency (A4A6) rely on the overarching assumption that family owners, managers and employees have near total discretion over resource acquisition, disposal, and allocation, which holds true until external governance mechanisms (such as trusts) are introduced (assumption A12). Also, under behavioral agency and SEW theories, the risk of losing SEW is assumed to cause riskaverse behavior (A7) yet the accuracy of this assumption has boundaries. For example, threats to the longevity of SEW and its stability may also motivate radical innovation (A8). This implies distress as a boundary condition.

Figure 1 presents the eight urgent research questions which need answering in order to move forward knowledge on family firm radical innovation. Allied to this, this study reveals the theoretical lenses and their assumptions attached to these research questions. The present study requests to scholars is to actively consider and question the theoretical assumptions underpinning their future studies and to consider where these assumptions compete or coexist with those of alternative theoretical lenses. In turn, more robust studies of family firm radical innovation can follow and ones that bridge some of the conflict found in predictions and findings about family firm radical innovation. This is directly allied to the research conversation about how, why, and on what basis family firms themselves differ from each other. The examination of the current study provides a research agenda to ensure important and timely contributions that build and scale current understanding of radical innovation as a crucial type of family firm innovation.

While this study generates insights and questions into radical innovation activities in family firms under four theoretical lenses, it is also important the future research does not lose sight of context. In family firm research, the internal context of the family firm is generally treated richly, as epitomized in studies of agency and behavioral agency, family resources, 
and family involvement in the willingness-ability paradox. However, the external context of the family firm also matters, but has rarely been given as much consideration. For example, dramatic changes in firms' external environments are becoming increasingly more frequent and pronounced. Digitalization is one such phenomenon ${ }^{2}$. Digitalization generates many technological impacts on the firm including its markets, business models, products and services. How radical innovation activities may enable the family firm to survive dramatic external environmental changes and in coupling with what other factors represents an interesting avenue for research. Based on the examination presented in this study, it is suggested that the answer lies in a combination or coming together of theoretical perspectives rather than one alone to explain family firm behavior in the face of dramatic technological shifts outside the business. Digitalization is defined as the extent to which a firm implements digital technologies (e.g., information technologies, artificial intelligence, and 3D printing) into its conventional business process (Bouncken et al., 2019). Digital technologies can widen information-sharing between a firm and external business market (from offline to online business) and quicken communication between employees and customers (Kraus et al., 2019a). Because of these, a firm can reach wider geographic markets (Bouncken et al., 2019), broaden the view of the CEO in searching business opportunities (Kraus et al., 2019a), and accelerating transformation processes among competences, activities and outputs (Bohnsack et al., 2018). The future direction can be driven by treating the level of digitalization as a factor within the RBV and capabilities lens or as a moderator when researchers are adopting ability and willingness theory as a lens to predict radical innovation in family firms. The time is ripe for a thorough investigation of radical innovation in family firms and this present study provides a foundation upon which future investigations of radical innovation in family firms can productively build.

\footnotetext{
${ }^{2}$ We thank an anonymous reviewer for this suggestion.
} 


\section{REFERENCES}

Anderson, R. and Reeb, D. (2003). "Founding-family ownership and firm performance: Evidence from the S\&P 500". Journal of Finance, Vol 58 No. 3, pp. 1301-1328.

Ashwin, A. S., Krishnan, R. T. and George, R. (2015). "Family firms in India: family involvement, innovation and agency and stewardship behaviors", Asia Pacific Journal of Management, Vol 32 No. 4, pp. 869-900.

Barczak, G., Griffin, A. and Kahn, K. (2009). "PERSPECTIVE: Trends and drivers of Success in NPD practices: Results of the 2003 PDMA best practices study", Journal of Product Innovation Management, Vol 26, pp. 3-33.

Barney, J. (1991). "Firm resources and sustained competitive advantage. Journal of Management", Vol 17 No. 1, pp. 99-120.

Berrone, P., Cruz, C. and Gomez-Mejia, L. (2012). "Socioemotional wealth in family firms: Theoretical dimensions, assessment approaches, and agenda for future research", Family Business Review, Vol 25 No. 3, pp. 258-279.

Berrone, P., Cruz, C., Gomez-Mejia, L. and Larraza-Kintana, M. (2010). "Socioemotional wealth and corporate resources to institutional pressures: Do family-controlled firms pollute less?", Administrative Science Quarterly, Vol 55 No. 1, pp. 82-113.

Block, J. (2012). "R\&D investments in family and founder firms: An agency perspective", Journal of Business Venturing, Vol 27 No. 2, pp. 248-265.

Bohnsack, R., Hanelt, A., Marz, D. and Antunes, C. (2018). "Old wine in new bottles? A systematic review of the literature on digital transformation", In Academy of Management global proceedings.

Bouncken, R., Fredrich, V., Ritala, P. and Kraus, S. (2018). "Coopetition in new production development alliances: Advantages and tensions for incremental and radical innovation", British Journal of Management, Vol 29, pp. 391-410.

Bouncken, R.B., Kraus, S. and Roig-Tierno, N. (2019). "knowledge- and innovation-based business models for future growth: digitalized business models and portfolio considerations", Review of Managerial Science.

Brinkerink, J. and Bammens, Y. (2018). "Family influence and R\&D spending in Dutch manufacturing SMEs: The role of identity and socioemotional decision considerations", Journal of Product Innovation Management, Vol 35 No. 4, pp. 588608.

Calabrò A., Vecchiarini M., Gast J., Campopiano G., De Massis A. and Kraus S. (2018). "Innovation in family firms: A systematic literature review and guidance for future research", International Journal of Management Reviews, Vol 21 No.3, pp. 317-355.

Carnes, C. and Ireland, R. (2013). "Familiness and innovation: resource bundling as the missing link", Entrepreneurship Theory and Practice, Vol 37 No. 6, pp. 1399-1419.

Carney, M. (2005). "Corporate governance and competitive advantage in family-controlled firms", Entrepreneurship Theory and Practice, Vol 29 No. 3, pp. 249-265.

Carney, M. and Gedajlovic, E. (2002). "The coupling of ownership and control and the allocation of financial resources: Evidence from Hong Kong”, Journal of Management Studies, Vol 39 No. 1, pp. 123-146.

Cassia, L., De Massis, A. and Pizzurno, E. (2011). "An exploratory investigation on NPD in small family business from northern Italy", International Journal of Management and Social Sciences, Vol 2 No. 2, pp. 1-14.

Cassia, L., De Massis, A. and Pizzurno, E. (2012). "Strategic innovation and new product development in family firms: An empirical grounded theoretical framework", International Journal of Entrepreneurial Behavior and Research, Vol 18 No. 2, pp. 198-232.

Cesinger, B., Hughes, M., Mensching, H., Bouncken, R., Fredrich, V. and Kraus, S. (2016). "A socioemotional wealth perspective on how collaboration intensity, trust, and international market knowledge affect family firms' multinationality", Journal of World Business, Vol 51 No. 4, pp. 586-599. 
Chandy, R. and Tellis, G. (1998). "Organizing for radical product innovation: The overlooked role of willingness to cannibalize", Journal of Marketing Research, Vol 35 No. 4, pp. 474-87.

Chandy, R. and Tellis, G. (2000). "The incumbent's curse? Incumbency, size, and radical product innovation", Journal of Marketing, Vol 64, pp. 1-17.

Chen, H. and Hsu, W. (2009). "Family ownership. board independence, and R\&D investment", Family Business Review, Vol 22 No. 4, pp. 347-362.

Cheng, Y. and Van de Ven, A. (1996). "Learning the innovation journey: Order out of chaos", Organization Science, Vol 7 No. 6, pp. 593-614.

Chirico, F. and Salvato, C. (2014). "Knowledge internalization and product development in family firms: When relational and affective factors matter", Entrepreneurship Theory and Practice, Vol 40 No. 1, pp. 201-229.

Chrisman, J. and Patel, P. (2012). "Variations in R\&D investments of family and non-family firms: Behavioral agency and myopic loss aversion perspectives", Academy of Management Journal, Vol 55 No. 4, pp. 976-997.

Chrisman, J., Chua, J. and Sharma, P. (2005). "Trends and directions in the development of a strategic management theory of the family firm", Entrepreneurship Theory and Practice, Vol 29 No. 5, pp. 555-576.

Chrisman, J., Chua, J., De Massis, A., Minola, T. and Vismara, S. (2016). "Management processes and strategy execution in family firms: From "what' to 'how'", Small Business Economics, Vol 47 No. 3, pp. 719-734.

Chrisman, J., Chua, J., Steier, L., Wright, M. and Mckee, D. (2012). “An agency theoretic analysis of value creation through management buy-outs of family firms", Journal of Family Business Strategy, Vol 3 No. 4, pp. 197-206.

Chrisman, J., Fang, H., Kotlar, J. and De Massis, A. (2015). "A note on family influence and the adoption of discontinuous technologies in family firms", Journal of Product Innovation Management", Vol 32 No. 3, pp. 384-388.

Chrisman, J., Sharma, P., Steier, L. and Chua, J. (2013). "The influence of family goals, governance, and resources on firm outcomes", Entrepreneurship Theory and Practice, Vol 37 No. 6, pp. 1249-1261.

Christensen, C. and Bower, J. (1996). "Customer power, strategic investment, and the failure of leading firms”, Strategic Management Journal, Vol 17 No. 3, pp. 197-218.

Chua, J., Chrisman, J., and Sharma, P. (1999). "Defining the family business by behavior", Entrepreneurship Theory and Practice, Vol 23 No. 4, pp. 19-39.

Colombo, M. G., Von Krogh, G., Rossi-Lamastra, C. and Stephan, P. (2017). "Organizing for radical innovation: Exploring novel insights”, Journal of Product Innovation Management, Vol 34 No. 4, pp. 394-405.

Corbetta, G. and Salvato, C. (2004). "Self-serving or self-actualizing? Models of man and agency costs in different types of family firms: A commentary on comparing the agency costs of family and non-family firms: Conceptual issues and exploratory evidence", Entrepreneurship Theory and Practice, Vol 28 No. 4, pp. 355-362.

Covin, J., Eggers, F., Kraus, S., Cheng, C. and Cheng, M. (2016). "Marketing-related resources and radical innovativeness in family and non-family firms: A configurational approach", Journal of Business Research, Vol 69 No. 12, pp. 56205627.

Craig, J. and Dibrell, C. (2006). "The natural environment, innovation, and firm performance: A comparative study", Family Business Review, Vol 19 No. 4, pp. 275-288.

Craig, J. and Moores, K. (2006). "Research note: A 10-year longitudinal investigation of strategy, systems, and environment on innovation in family firms", Family Business Review, Vol 19 No. 1: pp. 1-10.

Craig, J., Pohjola, M., Kraus, S. and Jensen, S. (2014). "Exploring relationships among proactiveness, risk-taking and innovation output in family and non-family firms", Creativity and Innovation Management, Vol 23 No. 2, pp. 199-210.

Cruz, C. and Nordqvist, M. (2012). "Entrepreneurial orientation in family firms: A generational perspective", Small Business Economics, Vol 38 No. 1, pp. 33-49.

Cucculelli, M., Le Breton-Miller, I. and Miller, D. (2016). "Product innovation, firm renewal and family governance", Journal of Family Business Strategy, Vol 7 No. 2, pp. 90104. 
Danes, S., Stafford, K., Haynes, G. and Amarapurkar, S. (2009). "Family capital of family firms", Family Business Review, Vol 22 No. 3, pp. 199-215.

Davis, J. H., Schoorman, F. D. and Donaldson, L. (1997). "Toward a Stewardship Theory of Management", Academy of Management Review, Vol 22 No. 1, pp. 20-47.

De Massis, A., Di Minin, A. and Frattini, F. (2015a). "Family-driven innovation: Resolving the paradox in family firms", California Management Review, Vol 58, pp. 5-19.

De Massis, A., Frattini, F. and Lichtenthaler, U. (2012). "Research on technological innovation in family firms: Present debates and future directions", Family Business Review, Vol 26 No. 1, pp. 10-31.

De Massis, A., Frattini, F., Kotlar, J., Petruzzeli, A. and Wright, M. (2016). "Innovation through tradition: Lessons from innovative family businesses and directions for future research", The Academy of Management Perspectives, Vol 30 No. 1, pp. 93-116.

De Massis, A., Kotlar, J., Campopiano, G. and Cassia, L. (2015b). "The impact of family involvement on SMEs' performance: Theory and evidence", Journal of Small Business Management, Vol 53 No. 4, pp. 924-948.

De Massis, A., Kotlar, J., Chua, J. and Chrisman, J. (2014). “Ability and willingness as sufficiency conditions for family-oriented particularistic behavior: Implications for theory and empirical studies", Journal of Small Business Management, Vol 52 No. 2 , pp. 344-364.

Dewar, R.D. and Dutton, J.E. (1986). "The adoption of radical and incremental innovations: An empirical analysis", Management Science, Vol 32, pp. 1422-1433.

Dunn, B. (1996). "Family enterprises in the UK: A special sector?", Family Business Review, Vol 9 No. 2, pp. 139-155.

Durand, R. and Vargas, V. (2003). “Ownership, organization, and private firms' efficient use of resources", Strategic Management Journal, Vol 24 No. 7, 667-675.

Eddleston, K. A. and Kellermanns, F. W. (2007). "Destructive and productive family relationships: A stewardship theory perspective", Journal of Business Venturing, Vol 22 No. 4, pp. 545-565.

Ettlie, J., Bridges, P. and O’Keefe, R. (1984). “Organization strategy and structural differences for radical versus incremental innovation", Management Science, Vol 30 No. 6, pp. 682-695.

Evanschitsky, H., Ramaseshan, B., Woisetschlager, D., Richelsen, V., Blut, M., and Backhaus, C. (2011). "Consequences of customer loyalty to the loyalty program and to the company", Journal of the Academy of Marketing Science, Vol 40 No. 5, pp. 625-638.

Faccio, M., Lang, L. and Young, L. (2001). "Dividends and expropriation”, American Economic Review, Vol 91 No. 1, pp. 54-78.

Feranita, F., Kotlar, J. and De Massis, A. (2017). "Collaborative innovation in family firms: Past research, current debates and agenda for future research", Journal of Family Business Strategy, Vol 8 No. 3, pp. 137-156.

Fernandez, Z. and Nieto, M. (2006). "Impact of ownership on the international involvement of SMEs. Journal of International Business Studies”, Vol 37 No. 3, pp. 340-351.

Filser, M., Brem, A., Gast, J., Kraus, S. and Calabro, A. (2016). "Innovation in family firms: Examining the inventory and mapping the path", International Journal of Innovation Management, Vol 20 No. 6, pp. 1650054.

Filser, M., De Massis, A., Gast, J., Kraus, S., and Niemand, T. (2018). "Tracing the roots of innovativeness in family SMEs: The effect of family functionality and socioemotional wealth", Journal of Product Innovation Management, Vol 35 No. 4, pp. 609-628.

Garcia, R. and Calantone, R. (2002). "A critical look at technological innovation typology and innovativeness terminology: A literature review", Journal of Product Innovation Management, Vol 19, pp. 110-132.

Gast, J., Filser, M., Rigtering, J.P.C., Harms, R., Kraus, S. and Chang, M.-L. (2018). "Socioemotional wealth and innovativeness in small- and medium-sized family enterprises: A configuration approach", Journal of Small Business Management, Vol 56 No. 1, pp. 53-67.

Gibbert, M., Hoegl, M. and Valikangas, L. (2007). "In praise of resource constraints", MIT Sloan Management Review, Vol 48 No. 3, pp. 15-17. 
Gomez-Mejia, L., Haynes, K., Nunez-Nickel, M., Jacobson, K. and Moyano-Fuentes, J. (2007). "Socioemotional wealth and business risks in family-controlled firms: Evidence from Spanish olive oil mills", Administrative Science Quarterly, Vol 52 No. 1, pp. 106-137.

Govindarajan, V. and Kopalle, P. (2006). "Disruptiveness of innovations: Measurement and an assessment of reliability and validity", Strategic Management Journal, Vol 27 No. 2, pp. 189-199.

Gudmundson, D., Tower, C. and Hartman, E. (2003). "Innovation in small businesses: Culture and ownership structure do matter", Journal of Developmental Entrepreneurship, Vol 8 No. 1, pp. 1-18.

Habbershon, T. and Williams, M. (1999). "A resources-based framework for assessing the strategic advantages of family firms", Family Business Review, Vol 12 No. 1, pp. 126.

Hall, A., Melin, L. and Nordqvist, M. (2001). "Entrepreneurship as radical change in the family business: Exploring the role of cultural patterns", Family Business Review, Vol 14 No. 3, pp. 193-208.

Hannan, M. and Freeman, J. (1977). "The population ecology of organizations", American Journal of Sociology, Vol 82 No. 5, pp. 929-964.

Hannan, M. and Freeman, J. (1984). "Structural inertia and organizational change", American Sociological Review, Vol 49 No. 2, pp. 149-164.

Harabi, N. (1995). "Appropriability of technical innovations an empirical analysis", Research Policy, Vol 24 No. 6, pp. 981-992.

Hart, C. (1998). Doing a Literature Review: releasing the social science research imagination. Sage, London.

Herrero, I. and Hughes, M. (2019). "When family social capital is too much of a good thing", Journal of Family Business Strategy, Vol 10 No. 3, pp. 100-271.

Hoffman, J., Hoelscher, M. and Sorenson, R. (2006). "Achieving sustained competitive advantage: A family capital theory", Family Business Review, Vol 19 No. 2, pp. 135145.

Huang, K., Lin, K., Wu, L. and Yu, P. (2015). "Absorptive capacity and autonomous R\&D climate roles in firm innovation", Journal of Business Research, Vol 68 No. 1, pp. 8794.

Hughes, M., Filser, M., Harms, R., Kraus, S., Chang, M.-L. and Cheng, C.-F. (2018). "Family firm configurations for high performance: The role of entrepreneurship and ambidexterity", British Journal of Management, Vol 29 No. 4, pp. 595-612.

Huybrechts, J., Voordeckers, W. and Lybaert, N. (2013). "Entrepreneurial Risk Taking of Private Family Firms: The Influence of a Nonfamily CEO and the Moderating Effect of CEO Tenure", Family Business Review, Vol 26 No. 2, pp. 161-179.

Ingram, A., Lewis, M., Barton, S. and Gartner, W. (2014). "Paradoxes and innovation in family firms: The role of paradoxical thinking", Entrepreneurship Theory and Practice, Vol 40 No. 1, pp. 161-176.

Kahneman, D. and Tversky, A. (1979). "Prospect theory: An analysis of decisions under risk", Econometrica, Vol 47 No. 2, pp. 263-292.

Kammerlander, N. and Ganter, M. (2015). "An attention-based view of family firm adaptation to discontinuous technological change: Exploring the role of family CEOs' noneconomic goals", Journal of Product Innovation Management, Vol 32 No. 3, pp. 361-383.

Kaplan, S., Murray, F. and Henderson, R. (2003). "Discontinuities and senior management: Assessing the role of recognition in pharmaceutical firm response to biotechnology", Industrial and Corporate Change, Vol 12 No. 2, pp. 203-233.

Kellermanns, F., Eddleston, K. and Zellweger, T. (2012). "Extending the socioemotional wealth perspective: A look at the dark side", Entrepreneurship Theory and Practice, Vol 36 No. 6, pp. 1175-1182.

Kellermanns, F., Eddleston, K., Barnett, T. and Pearson, A. (2008). "An exploratory study of family member characteristics and involvement: Effects on entrepreneurial behavior in the family firm", Family Business Review, Vol 21 No. 1, pp. 1-14. 
Koberg, C., Detienne, D. and Heppard, K. (2003). "An empirical test of environmental, organizational, and process factors affecting incremental and radical innovation", Journal of High Technology Management Research, Vol 14 No. 1, pp. 21-45.

Konig, A., Kammerlander, N. and Enders, A. (2013). "The family innovator's dilemma: How family influence affects the adoption of discontinuous technologies by incumbent firms", Academy of Management Review, Vol 38 No. 3, pp. 418-441.

Kor, Y. (2006). "Direct and interaction effects of top management team and board compositions on R\&D investment strategy", Strategic Management Journal, Vol 27 No. 11, pp. 1081-1099.

Kotlar, J., De Massis, A., Frattini, F., Bianchi, M. and Fang, H. (2013). “Technology acquisition in family and non-family firms: A longitudinal analysis of Spanish manufacturing firms", Journal of Product Innovation Management, Vol 30 No. 6, pp. 1073-1088.

Kraiczy, N., Hack, A. and Kellermanns, F. (2014). "New product portfolio performance in family firms", Journal of Business Research, Vol 67 No. 6, pp. 1065-1073.

Kraiczy, N., Hack, A. and Kellermanns, F. (2015). "What makes a family firm innovative? CEO risk-taking propensity and the organizational context of family firms", Journal of Product Innovation Management, Vol 32 No. 3, pp. 334-348.

Kraus, S., Breier, M. and Dasí-Rodríguez, S. (2020). "The art of crafting a systematic literature review in entrepreneurship research", International Entrepreneurship and Management Journal, in print.

Kraus, S., Kallmuenzer, A., Stieger, D., Peters, M. and Calabrò, A. (2018). "Entrepreneurial paths to family firm performance", Journal of Business Research, Vol 88, pp. 382387.

Kraus, S., Palmer, C., Kailer, N., Kallinger, F. and Spitzer, J. (2019a). "Digital entrepreneurship: a research agenda on new business models for the twenty-first century", International Journal of Entrepreneurial Behaviour \& Research, Vol 25, pp. 353-375.

Kyriakopoulos, K., Hughes, M. and Hughes, P. (2016). "The role of marketing resources in radical innovation activity: Antecedents and payoffs", Journal of Product Innovation Management, Vol 33 No. 4, pp. 398-417.

Le Breton-Miller, I., Miller, D. and Bares, F. (2015). "Governance and entrepreneurship in family firms: Agency, behavioral agency and resource-based comparisons", Journal of Family Business Strategy, Vol 6 No. 1, pp. 58-62.

Le Mens, G., Hannan, M. and Polos, L. (2015). "Age-related structural inertia: A distancebased approach", Organization Science, Vol 26 No. 3, pp. 756-773.

Li, Z. and Daspit, J. (2016). "Understanding family firm innovation heterogeneity: A typology of family governance and socioemotional wealth intentions", Journal of Family Business Management, Vol 6 No. 2, pp. 103-121.

Llach, J. and Nordqvist, M. (2010). "Innovation in family and non-family business: A resource perspective", International Journal of Entrepreneurship Venturing, Vol 2, pp. 381-399.

Lumpkin, G., Brigham, K. and Moss, T. (2010). "Long-term orientation: Implications for the entrepreneurial orientation and performance of family business", Entrepreneurship and Regional Development, Vol 22 No. 3-4, pp. 241-264.

Mallon, M. R., Lanivich, S. E. and Klinger, R. L. (2018). "Resource configurations for new family venture growth", International Journal of Entrepreneurial Behavior and Research, Vol 24 No. 2, pp. 521-537.

Mani, Y. and Lakhal, L. (2015). "Exploring the family effect on firm performance: The impact of internal social capital dimensions on family firm performance", International Journal of Entrepreneurial Behavior and Research, Vol 21 No. 6, pp. 898-917. 
Matzler, K., Veider, V., Hautz, J. and Stadler, C. (2015). "The impact of family ownership, management, and governance on innovation", Journal of Product Innovation Management, Vol 32 No. 3, pp. 319-333.

McConaughy, D., Walker, M., Henderson, G. and Mishra, C. (1998). "Founding family controlled firms: Efficiency and value", Review of Financial Economics, Vol 7 No. 1, pp. 1-19.

Mertens, D. (2005). Research and Evaluation in Education and Psychology, Sage, London: Sage.

Miller, D. (1993). "The architecture of simplicity", Academy of Management Review, Vol 18 No. 1, pp. 116-139.

Miller, D. and Le Breton-Miller, I. (2005). Managing for the long run: Lessons in competitive advantage from great family business. Harvard Business School Press, Boston.

Miller, D. and Le Breton-Miller, I. (2006). "Family governance and firm performance", Family Business Review, Vol 19 No. 1, pp. 73-87.

Miller, D., Le Breton-Miller, I. and Scholnick, B. (2008). "Stewardship vs. stagnation: An empirical comparison of small family and non-family businesses", Journal of Management Studies, Vol 45 No. 1, pp. 51-78.

Miller, D., Le Breton-Miller, I., Lester, R. and Cannella, A. (2007). "Are family firms really superior performers?", Journal of Corporate Finance, Vol 13 No. 5, pp. 829-858.

Miller, D., Wright, M., Le Breton-Miller, I. and Scholes, L. (2015). "Resources and innovation in family businesses: The Janus-face of family socioemotional preferences", California Management Review, Vol 58 No. 1, pp. 20-40.

Morck, R. and Yeung, B. (2003). "Agency problems in large family business groups", Entrepreneurship Theory and Practice, Vol 27 No. 4, pp. 367-382.

Munari, F., Oriani, R. and Sobrero, M. (2010). "The effects of owner identify and financial markets on R\&D investments: A study of Western European firms", Research Policy, Vol 39 No. 8, pp. 1093-1104.

Nieto, M., Santamaria, L. and Fernandez, Z. (2015). "Understanding the innovation behaviour of family firms", Journal of Small Business Management, Vol 53 No. 2, pp. 382-399.

Nordstrom, O. A. and Steier, L. (2015). "Social capital: a review of its dimensions and promise for future family enterprise research", International Journal of Entrepreneurial Behavior and Research, Vol 21 No. 6, pp. 801-813.

Patel, P. and Chrisman, J. (2014). "Risk abatement as a strategy for R\&D investments in family firms", Strategic Management Journal, Vol 35 No. 4, pp. 617-627.

Patel, P. and Fiet, J. (2011). "Knowledge combination and the potential advantages of family firms in searching for opportunities", Entrepreneurship Theory and Practice, Vol 35 No. 6, pp. 1179-1197.

Prajogo, D. (2016). "The strategic fit between innovation strategies and business environment in delivering business performance", International Journal Production Economics, Vol 171, pp. 241-249.

Roessl, D., Fink, M. and Kraus, S. (2010). "Are family firms fit for innovation? Towards an agenda for empirical research", International Journal of Entrepreneurial Venturing, Vol 2 No. 3-4, pp. 366-380.

Rod, I. (2016). "Disentangling the family firm's innovation process: A systematic review", Journal of Family Business Strategy. Vol 7, pp. 185-201.

Rubera, G. and Kirca, A. (2012). "Firm innovativeness and its performance outcomes: A meta-analytic review and theoretical integration", Journal of Marketing, Vol 76, pp. 130-147.

Scholes, L. and Wilson, N. (2014). "The importance of family firm trustees in family firm governance", Entrepreneurship Theory and Practice, Vol 38 No. 6, pp. 1285-1293.

Schulze, W., Lubatkin, M., Dino, R. and Buchholtz, A. (2001). "Agency relationships in family firms: Theory and evidence", Organization Science, Vol 12 No. 2, pp. 99-116.

Sciascia, S., Nordqvist, M., Mazzola, P. and De Massis, A. (2015). "Family ownership and R\&D intensity in small- and medium-sized firms", Journal of Product Innovation Management, Vol 32 No. 3, pp. 349-360. 
Sharma, P. and Salvato, C. (2011). "Commentary: Exploiting and exploring new opportunities over life cycle stages of family firms", Entrepreneurship Theory and Practice, Vol 35 No. 6, pp. 1199-1205.

Shleifer, A. and Vishny, R. (1997). "A survey of corporate governance", The Journal of Finance, Vol 52 No. 2, pp. 737-783.

Singh, D. and Gaur, A. (2013). "Governance structure, innovation and internationalization: Evidence from India", Journal of International Management, Vol 19 No. 3, pp. 300309.

Sirmon, D. and Hitt, M. (2003). "Managing resources: Linking unique resources, management, and wealth creation in family firms", Entrepreneurship Theory and Practice, Vol 27 No. 4, pp. 339-358.

Slater, S., Mohr, J. and Sengupta, S. (2013). "Radical product innovation capabilities: literature review, synthesis, and illustrative research propositions", Journal of Product innovation Management, Vol 31 No. 3, pp. 552-566.

Sorensen, J. and Stuart, T. (2000). "Aging, obsolescence, and organization innovation", Administrative Science Quarterly, Vol 45 No. 1: pp. 81-112.

Thomsen, S. and Pedersen, T. (2000). "Ownership structure and economic performance in the largest European companies”, Strategic Management Journal, Vol 21 No. 6, pp. 689705 .

Tripsas, M. and Gavetti, G. (2000). "Capabilities, cognition and inertia: Evidence from digital imaging”, Strategic Management Journal, Vol 21 No. 10-11, pp. 1147-1161.

Uhlaner, L., Stel, A., Duplat, V. and Zhou, H. (2013). "Disentangling the effects of organizational capabilities, innovation and firm size on SME sales growth", Small Business Economics, Vol 41 No. 3, pp. 581-607.

Veider, V. and Matzler, K. (2016). "The ability and willingness of family-controlled firms to arrive at organizational ambidexterity", Journal of Family Business Strategy, Vol 7 No. 2, pp. 105-116.

Venkatraman, N. and Camillus, J. (1984). 'Exploring the concept of 'fit' in strategic management", Academy of management, Vol 9 No. 3, pp. 513-525.

Wright, M., De Massis, A., Scholes, L., Hughes, M. and Kotlar, J. (2016). "Family Business Entrepreneurship", Report prepared for the Institute for Family Business Research Foundation.

Xiang, D., Chen, J., Tripe, D. and Zhang, N. (2018). "Family firms, sustainable innovation and financing cost: Evidence from Chinese hi-tech small and medium-sized enterprises", Technological Forecasting and Social Change, Vol 114, pp. 499-511.

Yu, D. and Hang, C. C. (2010). "A Reflective Review of Disruptive Innovation Theory", International Journal of Management Reviews, Vol 12 No. 4, pp. 435-452.

Zahra, S. (2003). "International expansion of U.S. manufacturing family business: The effect of ownership and involvement", Journal of Business Venturing, Vol 18 No. 4, pp. 495-512.

Zahra, S. (2005). "Entrepreneurial risk taking in family firms", Family Business Review, Vol 18 No. 1, pp. 23-40.

Zahra, S. (2012). "Organizational learning and entrepreneurship in family firms: Exploring the moderating effect of ownership and cohesion", Small Business Economics, Vol 38 No. 1, pp. 51-65.

Zahra, S. A. (2018). "Entrepreneurial risk taking in family firms: The wellspring of the regenerative capability", Family Business Review, Vol 31 No. 2, pp. 216-226.

Zahra, S., Hayton, J. and Salvato, C. (2004). "Entrepreneurship in family vs. non-family firms: A resource-based analysis of the effect of organizational culture", Entrepreneurship Theory and Practice, Vol 28 No. 4, pp. 363-381.

Zhang, F., Wei, L., Yang, J. and Zhu, L. (2018). "Roles of Relationships Between Large Shareholders and Managers in Radical Innovation: A Stewardship Theory Perspective", Journal of Product Innovation Management, Vol 35 No. 1, pp. 88-105. 
Table 1: Articles Directly Discussing or Supporting the RBV and Capabilities for Family Firm Radical Innovation

\begin{tabular}{|c|c|c|c|c|}
\hline Article & Paper type & Theories & Sample & Findings and arguments from the articles \\
\hline $\begin{array}{l}\text { Zahra et al. } \\
(2004) \\
\text { (Supporting) }\end{array}$ & Quantitative & RBV & $\begin{array}{l}536 \text { manufacturing } \\
\text { companies, U.S. }\end{array}$ & $\begin{array}{l}\text { 1. Diversification of employees' ability is positively related to entrepreneurial behavior (finding). } \\
\text { 2. Knowledge resources are crucial for family firms' innovation (arguments). }\end{array}$ \\
\hline $\begin{array}{l}\text { Cassia et al. } \\
\text { (2011) (Direct) }\end{array}$ & Qualitative & RBV & $\begin{array}{l}\text { Case study of } 4 \\
\text { family firms, Italy. }\end{array}$ & $\begin{array}{l}\text { High 'closure' in the attitudes of family firms is negatively related to NPD process (finding). } \\
\text { NPD process needs the high motivation of family firms (finding). }\end{array}$ \\
\hline $\begin{array}{l}\text { Cassia et al. } \\
(2012)\end{array}$ & $\begin{array}{l}\text { Grounded } \\
\text { theory }\end{array}$ & RBV & $\begin{array}{l}\text { Literature review; } \\
\text { case study on } 5 \\
\text { Italian family firms } \\
\text { and } 5 \text { Italian non- } \\
\text { family firms. }\end{array}$ & Family firms can reach a NPD long-term thrust if family firms are long-term oriented. \\
\hline $\begin{array}{l}\text { De Massis et al. } \\
\text { (2016) (Direct) }\end{array}$ & Qualitative & $\begin{array}{l}\text { Governance } \\
\text { structure } \\
\text { (Ownership and } \\
\text { management) }\end{array}$ & $\begin{array}{l}\text { Structured } \\
\text { literature review. }\end{array}$ & Providing an agenda to demonstrate how family firms innovate through tradition (finding). \\
\hline $\begin{array}{l}\text { Kraiczy et al. } \\
\text { (2014) (Direct) }\end{array}$ & Quantitative & $\begin{array}{l}\text { Upper echelon } \\
\text { theory }\end{array}$ & $\begin{array}{l}127 \text { TMT members } \\
\text { of } 63 \text { German } \\
\text { firms. }\end{array}$ & $\begin{array}{l}\text { New product development is positively related to multiple generations involved in TMT } \\
\text { (finding). }\end{array}$ \\
\hline $\begin{array}{l}\text { Patel and Fiet } \\
\text { (2011) } \\
\text { (Supporting) }\end{array}$ & Qualitative & RBV & $\begin{array}{l}\text { Structured } \\
\text { literature review. }\end{array}$ & $\begin{array}{l}\text { 1. Family firms have advantages in enduring knowledge structures, faster response to } \\
\text { opportunities, combining diversified of knowledge sets, and creating economies of scope } \\
\text { (finding). } \\
\text { 2. When family survivability is threatened, firms will search for alternatives (argument). }\end{array}$ \\
\hline $\begin{array}{l}\text { Sirmon and Hitt } \\
\text { (2003) } \\
\text { (Supporting) }\end{array}$ & Qualitative & RBV & $\begin{array}{l}\text { Structured } \\
\text { literature review. }\end{array}$ & $\begin{array}{l}\text { 1. Family firms have five idiosyncratic resources from which to create competitive advantages } \\
\text { (family human capital, family social capital, family patient capital, survivability capital, } \\
\text { governance structure, costs) (finding). } \\
\text { 2. Compared to non-family firms, family firms have advantages in pursuing innovation activities } \\
\text { by relying on these resources (argument). }\end{array}$ \\
\hline $\begin{array}{l}\text { Xiang et al. } \\
(2018) \\
\text { (Supporting) }\end{array}$ & Quantitative & RBV & $\begin{array}{l}958 \text { hi-tech family } \\
\text { SMEs in China. }\end{array}$ & $\begin{array}{l}\text { The conversion rate of innovation input into output is significantly related to the degree of } \\
\text { financial resources the family firms are willing to support (argument). }\end{array}$ \\
\hline $\begin{array}{l}\text { Nordstrom and } \\
\text { Steier }(2015)\end{array}$ & Qualitative & Social capital & Conceptual model. & $\begin{array}{l}\text { Family social capital has structural dimension, relational dimension and cognitive dimension. } \\
\text { Each dimension bears unique effects on innovation behaviors of family firms. }\end{array}$ \\
\hline $\begin{array}{l}\text { Mani and Lakhal } \\
(2015)\end{array}$ & Quantitative & Social capital & $\begin{array}{l}114 \text { Tunisian } \\
\text { family firms. }\end{array}$ & $\begin{array}{l}\text { 1. Cognitive dimension is positively related to financial performance in family firms. } \\
\text { 2. Both structural and relational dimensions are positively related to financial performance in } \\
\text { both family and non-family firms. }\end{array}$ \\
\hline
\end{tabular}




\begin{tabular}{|c|c|c|c|c|}
\hline $\begin{array}{l}\text { Mallon et al. } \\
(2017)\end{array}$ & $\begin{array}{l}\text { Fuzzy-set } \\
\text { qualitative } \\
\text { comparative } \\
\text { analysis }\end{array}$ & RBV & $\begin{array}{l}4928 \text { new ventures } \\
\text { founded in } 2004 \text { in } \\
\text { the USA. }\end{array}$ & $\begin{array}{l}\text { The combination between human capital and social capital, between human capital and financial } \\
\text { capital is sufficient for growing family ventures. }\end{array}$ \\
\hline $\begin{array}{l}\text { Chirico and } \\
\text { Salvato (2014) } \\
\text { (Supporting) }\end{array}$ & Quantitative & $\begin{array}{l}\text { Knowledge } \\
\text { internalization } \\
\text { and product } \\
\text { development }\end{array}$ & $\begin{array}{l}592 \text { firms, } \\
\text { Switzerland. }\end{array}$ & $\begin{array}{l}\text { 1. Dense social capital will decrease innovation ability within family firms because family } \\
\text { members will over-rely on their social capital (finding). } \\
\text { 2. Social capital has an inverted U-shaped relationship with the pursuit of conducting product } \\
\text { development processing (argument). }\end{array}$ \\
\hline $\begin{array}{l}\text { Sharma and } \\
\text { Salvato (2011) } \\
\text { (Supporting) }\end{array}$ & Qualitative & Ambidexterity & $\begin{array}{l}\text { Structured } \\
\text { literature review. }\end{array}$ & $\begin{array}{l}\text { 1. Incremental innovation is largely helpful when family firms are at the grown-up stage. Radical } \\
\text { innovation is needed when the market is highly saturated (finding). } \\
\text { 2. To achieve high firm performance, family firms need to combine incremental and radical } \\
\text { innovation together (argument). }\end{array}$ \\
\hline $\begin{array}{l}\text { Covin et al. } \\
\text { (2016) (Direct) }\end{array}$ & $\begin{array}{l}\text { Fuzzy-set } \\
\text { qualitative } \\
\text { comparative } \\
\text { analysis }\end{array}$ & $\begin{array}{l}\text { RBV (resource } \\
\text { bundle) }\end{array}$ & $\begin{array}{l}1749 \text { responses } \\
\text { across } 4 \text { European } \\
\text { countries. }\end{array}$ & $\begin{array}{l}\text { The combination of customer responses, social network and innovation motivation is positively } \\
\text { related to radical innovativeness in family firms. Adding financial resources will maximize this } \\
\text { relationship (finding). }\end{array}$ \\
\hline $\begin{array}{l}\text { Craig and } \\
\text { Moores (2006) } \\
\text { (Supporting) }\end{array}$ & Quantitative & $\begin{array}{l}\text { Four-stage life- } \\
\text { cycle }\end{array}$ & $\begin{array}{l}67 \text { companies } \\
\text { longitudinal } \\
\text { studies, Australia. }\end{array}$ & $\begin{array}{l}\text { 1. The relationship between techno-economic uncertainty and innovation is weaker in the later } \\
\text { stage than that in the early stage of family firms' organizational life-cycle (finding). } \\
\text { 2. Innovation activities are less prevalent in established firms than young firms (argument). }\end{array}$ \\
\hline $\begin{array}{l}\text { Huang et al. } \\
(2015) \\
\text { (Supporting) }\end{array}$ & Quantitative & $\begin{array}{l}\text { Absorptive } \\
\text { capacity }\end{array}$ & 165 firms, Taiwan. & $\begin{array}{l}\text { 1. Absorptive capacity moderates the relationship between R\&D expenditure and innovation } \\
\text { (finding). } \\
\text { 2. Absorptive capacity can help facilitate innovation (argument). }\end{array}$ \\
\hline $\begin{array}{l}\text { Uhlaner et al. } \\
(2013) \\
\text { (Supporting) }\end{array}$ & Quantitative & $\begin{array}{l}\text { Dynamic } \\
\text { capability }\end{array}$ & $\begin{array}{l}229 \text { firms, } \\
\text { Netherlands. }\end{array}$ & $\begin{array}{l}\text { 1. External resources are positively related to sales growth (finding). } \\
\text { 2. Resources are important for family firms to pursue innovation (argument). }\end{array}$ \\
\hline $\begin{array}{l}\text { Craig et al. } \\
(2014) \\
\text { (Supporting) }\end{array}$ & Quantitative & $\begin{array}{l}\text { Entrepreneurial } \\
\text { orientation }\end{array}$ & $\begin{array}{l}127 \text { food industry, } \\
246 \text { media, and } \\
159 \text { shipbuilding } \\
\text { firms, Finland. }\end{array}$ & $\begin{array}{l}\text { 1. Risk-taking does not impact on innovation output (finding). } \\
\text { 2. There is no relationship between risk-taking behavior and innovation outputs (argument). }\end{array}$ \\
\hline $\begin{array}{l}\text { Chrisman et al. } \\
(2016) \\
\text { (Supporting) }\end{array}$ & Qualitative & $\begin{array}{l}\text { Execution } \\
\text { behavior }\end{array}$ & $\begin{array}{l}\text { Structured } \\
\text { literature review. }\end{array}$ & $\begin{array}{l}\text { Although family owners have strong willingness to pursue innovation activities, the adoption of } \\
\text { innovation is less likely when firms have fewer supporting resources (argument). }\end{array}$ \\
\hline
\end{tabular}

Table 2: Articles Directly Discussing or Supporting Agency Theory and Stewardship Theory in the Context of Family Firm Radical Innovation Paper type 


\begin{tabular}{|c|c|c|c|c|}
\hline $\begin{array}{l}\text { Chrisman et al. } \\
\text { (2012) } \\
\text { (Supporting) }\end{array}$ & Qualitative & $\begin{array}{l}\text { Agency theory, } \\
\text { ability and } \\
\text { willingness }\end{array}$ & $\begin{array}{l}\text { Structured literature } \\
\text { review. }\end{array}$ & $\begin{array}{l}\text { 1. Different agency types will generate different agency costs, which will influence future } \\
\text { firm strategies in non-family management buy-in or buy-out (finding). } \\
\text { 2. Unified family governance structure constrains family firms' risk-taking behavior and } \\
\text { willingness to innovate (argument). }\end{array}$ \\
\hline $\begin{array}{l}\text { Chrisman et al. } \\
(2005) \\
\text { (Supporting) }\end{array}$ & Qualitative & $\begin{array}{l}\text { RBV and agency } \\
\text { theory }\end{array}$ & $\begin{array}{l}\text { Structured literature } \\
\text { review. }\end{array}$ & $\begin{array}{l}\text { 1. Family involvement will influence family firms' performance (finding). } \\
\text { 2. Family involvement can increase altruism and entrenchment, which nullify the value of } \\
\text { existing capabilities and slow down the development of new capabilities (argument). }\end{array}$ \\
\hline $\begin{array}{l}\text { De Massis et al. } \\
\text { (2012) (Direct) }\end{array}$ & Qualitative & Agency theory & $\begin{array}{l}\text { Structured literature } \\
\text { review. }\end{array}$ & $\begin{array}{l}\text { 1. Family involvement has direct influence on R\&D expenditure, and number of new } \\
\text { products (finding). } \\
2 \text {. This study also introduces the gaps within the relationships among innovation input, } \\
\text { output, and activities, which provides a basis for future family firms and technology } \\
\text { innovation studies (argument). }\end{array}$ \\
\hline $\begin{array}{l}\text { Singh and Gaur } \\
\text { (2013) (Direct) }\end{array}$ & Quantitative & Agency theory & $\begin{array}{l}4946 \text { firms in } \\
\text { Bombay Stock } \\
\text { Exchange, India. }\end{array}$ & Family ownership has a positive relationship with R\&D intensity in a new market (finding). \\
\hline $\begin{array}{l}\text { Zahra (2005) } \\
\text { (Direct) }\end{array}$ & Quantitative & $\begin{array}{l}\text { Agency theory, } \\
\text { entrepreneurship }\end{array}$ & $\begin{array}{l}497 \text { responses from } \\
209 \text { manufacturing } \\
\text { firms, U.S. }\end{array}$ & $\begin{array}{l}\text { Family ownership and involvement have a positive relationship with technological } \\
\text { innovation (finding). } \\
\text { Long CEO tenure has a negative relationship with technological innovation (finding). }\end{array}$ \\
\hline $\begin{array}{l}\text { Chen and Hsu } \\
(2009) \\
\text { (Supporting) }\end{array}$ & Quantitative & $\begin{array}{l}\text { Family ownership } \\
\text { and R\&D } \\
\text { investment }\end{array}$ & $\begin{array}{l}124 \text { responses from } \\
76 \text { firms, Taiwan. }\end{array}$ & $\begin{array}{l}\text { 1. Family ownership is negatively associated with R\&D expenditure (finding). } \\
\text { 2. Family firms will spend less on R\&D while family owners are maintaining business } \\
\text { control for the next-generation leader (argument). }\end{array}$ \\
\hline $\begin{array}{l}\text { Block (2012) } \\
\text { (Direct) }\end{array}$ & Qualitative & Agency theory & $\begin{array}{l}154 \text { firms listed in } \\
\text { the S\&P 500, U.S. }\end{array}$ & $\begin{array}{l}\text { Founder involvement has a positive relationship with innovation activities at a later stage of } \\
\text { family firms' organizational life-cycle (finding). }\end{array}$ \\
\hline $\begin{array}{l}\text { Kellermanns et al. } \\
\text { (2012) (Direct) }\end{array}$ & Quantitative & $\begin{array}{l}\text { Agency and } \\
\text { stewardship }\end{array}$ & $\begin{array}{l}126 \text { responses from } \\
70 \text { firms, U.S. }\end{array}$ & $\begin{array}{l}\text { 1. Innovativeness in family firms is positively associated with family firm performance } \\
\text { (finding). } \\
\text { 2. Family involvement will increase the degree of ownership dispersion over family } \\
\text { members and, in turn, increase conflicts among family members (argument). }\end{array}$ \\
\hline $\begin{array}{l}\text { Le Breton-Miller } \\
\text { et al. (2015) } \\
\text { (Supporting) }\end{array}$ & Qualitative & $\begin{array}{l}\text { Agency theory, } \\
\text { Behavioral } \\
\text { agency theory, } \\
\text { RBV }\end{array}$ & $\begin{array}{l}\text { Structured literature } \\
\text { review. }\end{array}$ & $\begin{array}{l}\text { 1. Both agency theory and behavioral agency theory can positively and negatively influence } \\
\text { entrepreneurship behavior of family firm (finding). } \\
\text { 2. High levels of tenure are negatively related to firms' entrepreneurship behavior } \\
\text { (argument). } \\
\text { 3. The number of the family member present on the board of directors is positively related to } \\
\text { entrepreneurship behavior (argument). } \\
\text { 4. Family involvement in management is positively related to entrepreneurship behavior } \\
\text { (argument). }\end{array}$ \\
\hline $\begin{array}{l}\text { Matzler et al. } \\
(2015) \text { (Direct) }\end{array}$ & Quantitative & Agency theory & 829 firms, Europe. & There is a negative relationship between family ownership and R\&D intensity (finding). \\
\hline
\end{tabular}




\begin{tabular}{|c|c|c|c|c|}
\hline $\begin{array}{l}\text { Carney (2005) } \\
\text { (Supporting) }\end{array}$ & Qualitative & $\begin{array}{l}\text { Agency theory, } \\
\text { RBV }\end{array}$ & $\begin{array}{l}\text { Structured literature } \\
\text { review. }\end{array}$ & $\begin{array}{l}\text { 1. There are three types of family firm governance propensities, parsimonious, particularism } \\
\text { and personalism (finding). } \\
\text { 2. Innovation activities are more likely when the combination of particularism and } \\
\text { personalism governance propensity is present (argument). }\end{array}$ \\
\hline $\begin{array}{l}\text { Filser et al. (2018) } \\
\text { (Supporting) }\end{array}$ & Quantitative & $\begin{array}{l}\text { Agency theory, } \\
\text { SEW }\end{array}$ & $\begin{array}{l}161 \text { family firms, } \\
\text { Finland. }\end{array}$ & $\begin{array}{l}\text { Family involvement can increase conflicts between family members unless they have a } \\
\text { common interest to pursue (argument). }\end{array}$ \\
\hline $\begin{array}{l}\text { Ashwin et al. } \\
\text { (2015) (Direct) }\end{array}$ & Quantitative & $\begin{array}{l}\text { Agency and } \\
\text { Stewardship } \\
\text { theory }\end{array}$ & $\begin{array}{l}172 \text { firms from } \\
\text { India. }\end{array}$ & $\begin{array}{l}\text { Family involvement is positively related to R\&D expenditure when stewardship behavior is } \\
\text { at a high degree (finding). }\end{array}$ \\
\hline $\begin{array}{l}\text { Miller et al. } \\
(2008) \\
\text { (Supporting) }\end{array}$ & Qualitative & $\begin{array}{l}\text { Stewardship } \\
\text { theory }\end{array}$ & $\begin{array}{l}22 \text { interviews, } \\
\text { CEOs from family } \\
\text { firms in Canada }\end{array}$ & $\begin{array}{l}\text { Extending business continuity is a way to increase stewardship thinking among family } \\
\text { members (argument). }\end{array}$ \\
\hline $\begin{array}{l}\text { Eddleston and } \\
\text { Kellermanns } \\
\text { (2007) } \\
\text { (Supporting) }\end{array}$ & Quantitative & $\begin{array}{l}\text { Stewardship } \\
\text { theory }\end{array}$ & $\begin{array}{l}107 \text { family firms } \\
\text { from the US. }\end{array}$ & $\begin{array}{l}\text { 1. Stewardship behavior is emphasized while family firms are maintaining business control } \\
\text { for the next-generation leader (argument). } \\
\text { 2. Stewardship behavior is motivated by reciprocity which is induced by altruism and family } \\
\text { bonds (argument). }\end{array}$ \\
\hline $\begin{array}{l}\text { Huybrechts et al. } \\
(2012)\end{array}$ & Quantitative & Agency theory & $\begin{array}{l}740 \text { private firms } \\
\text { with } 555 \text { family } \\
\text { firms within from } \\
\text { Belgium. }\end{array}$ & $\begin{array}{l}\text { When succession is approaching, family owners will pay attention to reinforce stability to } \\
\text { safeguard business for future generations (argument). }\end{array}$ \\
\hline
\end{tabular}

Table 3: Articles Directly Discussing or Supporting Behavioral Agency and SEW Theory in the Context of Family Firm Radical Innovation

\begin{tabular}{|l|l|l|l|l|}
\hline Article & Paper type & Theories & Sample & Finding and arguments from the articles \\
\hline $\begin{array}{l}\text { Kammerlander } \\
\text { and Ganter (2015) } \\
\text { (Direct) }\end{array}$ & Quantitative & $\begin{array}{l}\text { Attention-based } \\
\text { view, SEW }\end{array}$ & $\begin{array}{l}\text { Case study of 8 } \\
\text { firms, Germany. }\end{array}$ & $\begin{array}{l}\text { 1. Economic and noneconomic goals are mutually reinforcing when family firms are } \\
\text { experiencing intense firm development (finding). } \\
\text { 2. Different noneconomic goals lead to different firm radical innovation behaviors (finding). }\end{array}$ \\
\hline $\begin{array}{l}\text { Gomez-Mejia et } \\
\text { al. (2007) }\end{array}$ & Quantitative & $\begin{array}{l}\text { Behavioral } \\
\text { Agent theory, } \\
\text { SEW }\end{array}$ & 1237 firms, Spain. & $\begin{array}{l}\text { 1. Family firms will largely avoid risk-taking for the sake of preserving SEW endowment. } \\
\text { However, family firms can be highly innovative when SEW endowment suffers a significant } \\
\text { loss (finding). } \\
\text { 2. The behavior of preserving SEW will gradually block innovation activities during firm } \\
\text { development (argument). }\end{array}$ \\
\hline $\begin{array}{l}\text { Chrisman and } \\
\text { Patel (2012) } \\
\text { Supporting) }\end{array}$ & Quantitative & $\begin{array}{l}\text { Behavioral } \\
\text { Agency theory, } \\
\text { SEW }\end{array}$ & 964 firms, U.S. & $\begin{array}{l}\text { 1. When results are below aspirations, family firms will move into loss mode and then increase } \\
\text { 2. Increases in investment-time horizon can reduce risk-averse behavior and increase R\&D } \\
\text { expenditure (finding). }\end{array}$ \\
\hline
\end{tabular}




\begin{tabular}{|c|c|c|c|c|}
\hline & & & & $\begin{array}{l}\text { 3. SEW dimensions can direct family firms' attention towards either conservative or highly } \\
\text { innovative behavior (argument). }\end{array}$ \\
\hline $\begin{array}{l}\text { Berrone et al. } \\
(2012) \\
\text { (Supporting) }\end{array}$ & Quantitative & $\begin{array}{l}\text { Behavioral } \\
\text { Agency theory, } \\
\text { SEW }\end{array}$ & $\begin{array}{l}43 \text { family and } 43 \\
\text { non-family firms, } \\
\text { U.S. }\end{array}$ & $\begin{array}{l}\text { 1. SEW consists of FIBER dimensions (finding). } \\
\text { 2. SEW can change state at any point in time and generate different innovative behavior } \\
\text { (argument). }\end{array}$ \\
\hline $\begin{array}{l}\text { Miller et al. } \\
(2015) \\
\text { (Supporting) }\end{array}$ & Qualitative & $\begin{array}{l}\text { SEW and } \\
\text { Willingness }\end{array}$ & $\begin{array}{l}\text { A case study of } 4 \\
\text { firms, UK. }\end{array}$ & $\begin{array}{l}\text { 1. SEW can generate two extreme behaviors and influence the decision to pursue innovation: } \\
\text { 'Creating an evergreen organization' (CAEO) directs family firms to make innovation } \\
\text { decisions for firms' development; while 'feeding parochial family desires' (FPFD) directs } \\
\text { firms to maintain the status quo by acting conservatively and avoid risk (finding). } \\
\text { 2. SEW dimensions are the key factors to influence the creation of innovation goals } \\
\text { (argument). }\end{array}$ \\
\hline $\begin{array}{l}\text { Brinkerink and } \\
\text { Bammens (2019) } \\
\text { (Supporting) }\end{array}$ & Quantitative & $\begin{array}{l}\text { SEW, social } \\
\text { identify theory }\end{array}$ & $\begin{array}{l}365 \text { SMEs in } \\
\text { Netherlands. }\end{array}$ & $\begin{array}{l}\text { 1. family owners concern with preserving family control will reduce family firms 'willingness } \\
\text { to invest in R\&D (finding). } \\
\text { 2. R\&D investment would be slighted increased when family owners concern with extending } \\
\text { family firm continuity (finding). }\end{array}$ \\
\hline $\begin{array}{l}\text { Kraiczy et al. } \\
\text { (2014) (Direct) }\end{array}$ & Quantitative & SEW & $\begin{array}{l}63 \text { non-family firms } \\
\text { and } 114 \text { family } \\
\text { firms, Germany. }\end{array}$ & $\begin{array}{l}\text { CEO's risk propensity is positively associated with new product portfolio innovativeness. This } \\
\text { relationship is stronger in the early stage than in later stage of the organizational life-cycle } \\
\text { (finding). }\end{array}$ \\
\hline $\begin{array}{l}\text { Konig et al. } \\
(2013) \text { (Direct) }\end{array}$ & Qualitative & 4C framework & $\begin{array}{l}\text { Structured literature } \\
\text { review. }\end{array}$ & $\begin{array}{l}\text { Family firms have high speed and stamina for implementing radical innovation strategies } \\
\text { when family firms have made the decision to pursue the innovation strategies (finding). }\end{array}$ \\
\hline $\begin{array}{l}\text { Chrisman et al. } \\
\text { (2015) (Direct) }\end{array}$ & Qualitative & 4C framework & $\begin{array}{l}\text { Structured literature } \\
\text { review. }\end{array}$ & $\begin{array}{l}\text { Ability and willingness paradox plagues family firm innovation. However, family firms will } \\
\text { not survive without innovation activities (finding). }\end{array}$ \\
\hline
\end{tabular}


Table 4: Articles Directly Discussing or Supporting Ability and Willingness Theory in the Context of Family Firm Radical Innovation

\begin{tabular}{|c|c|c|c|c|}
\hline Article & Paper type & Theories & Sample & Findings and arguments from the articles \\
\hline $\begin{array}{l}\text { Chrisman et al. } \\
\text { (2015) (Direct) }\end{array}$ & Qualitative & $\begin{array}{l}\text { Ability and } \\
\text { willingness }\end{array}$ & $\begin{array}{l}\text { Structured literature } \\
\text { review. }\end{array}$ & $\begin{array}{l}\text { Although increasing family involvement is positively associated with family owner-managers' } \\
\text { discretion to allocate resources to innovation, family involvement is not necessarily related to } \\
\text { the willingness to pursue radical innovation (finding). }\end{array}$ \\
\hline $\begin{array}{l}\text { Veider and } \\
\text { Matzler (2015) } \\
\text { (Supporting) }\end{array}$ & Qualitative & $\begin{array}{l}\text { Ability and } \\
\text { willingness }\end{array}$ & $\begin{array}{l}\text { Structured literature } \\
\text { review. }\end{array}$ & $\begin{array}{l}\text { 1. Ability and willingness paradox is not a general rule in every family firm. Innovative } \\
\text { behavior depends on the goals of family firms (finding). } \\
\text { 2. Family firms' willingness to innovate is based on how family firms face challenges from the } \\
\text { external environment (argument). }\end{array}$ \\
\hline $\begin{array}{l}\text { De Massis et al. } \\
\text { (2014) } \\
\text { (Supporting) }\end{array}$ & Qualitative & $\begin{array}{l}\text { Ability and } \\
\text { willingness }\end{array}$ & $\begin{array}{l}\text { Structured literature } \\
\text { review. }\end{array}$ & $\begin{array}{l}\text { 1. Family-oriented behavior is generated by combining ability and willingness together } \\
\text { (finding). } \\
\text { 2. Innovation activities of family firms are influenced by ability and willingness (argument). }\end{array}$ \\
\hline $\begin{array}{l}\text { Ingram et al. } \\
(2014) \\
\text { (Supporting) }\end{array}$ & Qualitative & Paradox theory & $\begin{array}{l}178 \text { executive } \\
\text { responses from } 125 \\
\text { firms. }\end{array}$ & $\begin{array}{l}\text { 1. CEO with paradoxical thinking can increase innovation behavior (finding). } \\
\text { 2. Family employees' knowledge and ability matter for pursuing innovation activities } \\
\text { (argument). }\end{array}$ \\
\hline $\begin{array}{l}\text { Miller et al. } \\
\text { (2015) } \\
\text { (Supporting) }\end{array}$ & Qualitative & $\begin{array}{l}\text { SEW and } \\
\text { Willingness }\end{array}$ & $\begin{array}{l}\text { A case study of } 4 \\
\text { firms, UK. }\end{array}$ & $\begin{array}{l}\text { 1. SEW can generate two extreme behaviors and influence the decision to pursue innovation: } \\
\text { 'Creating an evergreen organization' (CAEO) directs family firms to make innovation } \\
\text { decisions for firms' development; while 'feeding parochial family desires' (FPFD) directs } \\
\text { firms to maintain the status quo by acting conservatively and avoid risk (finding). } \\
\text { 2. SEW dimensions are the key factors to influence the creation of innovation goals } \\
\text { (argument). }\end{array}$ \\
\hline $\begin{array}{l}\text { Zahra (2018) } \\
\text { (Supporting) }\end{array}$ & Qualitative & $\begin{array}{l}\text { RBV, SEW, } \\
\text { Ambidexterity }\end{array}$ & $\begin{array}{l}\text { Structured literature } \\
\text { review. }\end{array}$ & $\begin{array}{l}\text { The changing Innovation behavior towards either incremental or radical is to overcome the } \\
\text { challenge generated from environmental dynamism (argument). }\end{array}$ \\
\hline $\begin{array}{l}\text { Cucculelli et al. } \\
\text { (2016) (Direct) }\end{array}$ & Quantitative & $\begin{array}{l}\text { RBV, } \\
\text { Governance, } \\
\text { Willingness }\end{array}$ & $\begin{array}{l}3200 \text { companies, } \\
\text { Italy. }\end{array}$ & Radical innovation activities are highly dependent on founders' risk-taking behavior (finding) \\
\hline
\end{tabular}


Figure 1: Theoretical Assumptions and Future Research Agenda

Theoretical assumptions for family firm radical innovation

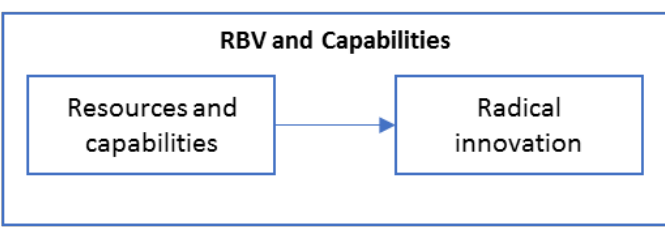

A1: High family firm idiosyncratic resources generate higher propensity for radical innovation (cf. A2)

A2: High tradition generates lower propensity for radical innovation (cf. A1)

A3: High degree of founder, owner-managers and next generation leaders' knowledge generates higher propensity for radical innovation (cf. A6)

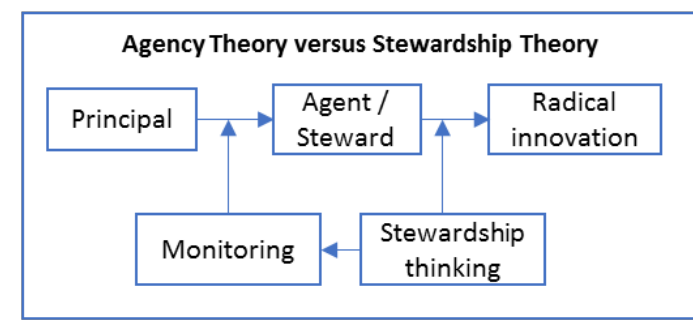

A4: Unified governance structures provides family owners with
power to control the firm's strategic direction and act
opportunistically (cf. A12)
A5: Under personalism and particularism governance properties,
family owners prioritize their own goals and interests in making
strategic decisions
A6: Family members make conservative venture investment
unless the venture investment is highly aligned with the goals of
family owners

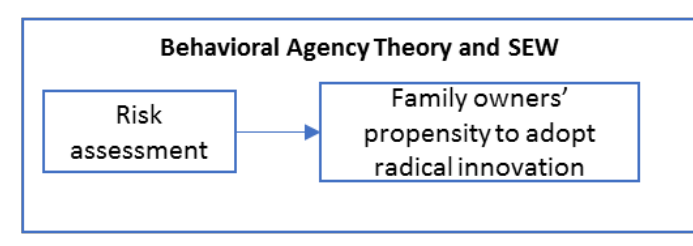

A7: To decrease the risk of losing SEW, family firms act in risk averse ways (cf. A8)

A8: To extend SEW, family firms are willing to pursue radical

innovation, but when longevity of SEW is threatened or

destabilised, family firms will engage in incremental innovation instead (cf. A7)

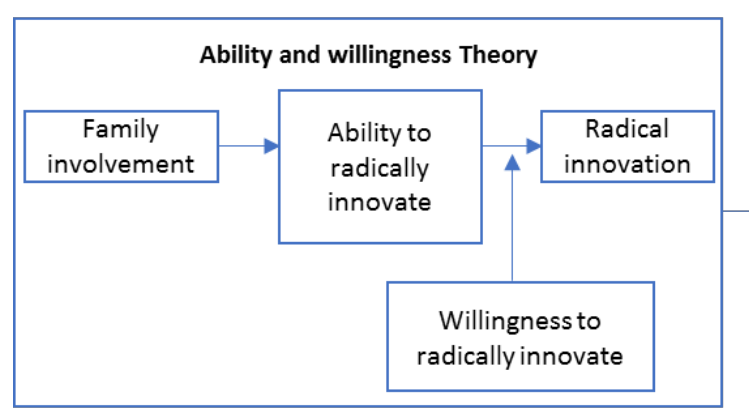

\section{A9: Ability to radically innovate is a function of resource} availability

A10: Radical innovation activities are mitigated by willingness A11: Willingness is driven by family goals

A12: Specific forms of governance can alter family owners' and managers' ability to dispose of and change assets and alter their willingness to set new goals (cf. A1-6)

$A=$ Assumption

\section{Research questionsand future research agenda}

Research question 1: What resource bundles should family firms possess or develop to facilitate radical innovation? Are there specific resource histories and trajectories that create facilitate or hinder the family firm in terms of radical innovation activities?

Research question 2: What kind and degree of knowledge should the family founder(s), owner-manager(s), or next-generation leader(s) possess, acquire or seek to build within the family firm to change the system of constraints in favour of radical innovation?

Research question 3: Under what conditions does a family unit treat radical innovation project as being in line with the interests of family members? What family properties encourage radical innovation as opposed to more conservative courses of actions?

Research question 4: How do family firms foster and maintain stewardship thinking among family members to support family firm radical innovation activities? In what ways do family firms foster stewardship behavior to support family firm radical innovation while preserving control for nextgeneration leaders?

Research question 5: Can a multi-dimensional conceptualization of SEW both support and dilute radical innovation? Does a dimensional conceptualization of SEW carry greater predictive accuracy than a unidimensional conceptualization?

Research question 6: What factors drive family SEW towards the CAEO dimension, increase willingness to pursue radical innovation and construct relevant, innovative goals?

Research question 7: How does environmental dynamism alter the relationship between (a) CAEO intensity and degree of pursuit of radical innovation and (b) the relationship between FPFD intensity and degree of pursuit of radical innovation within family firms?

Research question 8: What are the conditions that favor family firm radical innovation through collaborative or open means? 


\section{APPENDIX}

Appendix 1: Breakdown of 18 theories used in the study of family firm radical innovation

\begin{tabular}{|l|l|}
\hline Theory & Number of instances \\
\hline RBV & 11 \\
\hline Agency theory & 15 \\
\hline Stewardship theory & 4 \\
\hline Entrepreneurship & 1 \\
\hline Four-stage life-cycle & 1 \\
\hline Bebavioral agency theory and SEW & 10 \\
\hline Family ownership and R\&D investment & 1 \\
\hline Ambidexterity & 2 \\
\hline Ability and willingness & 4 \\
\hline Dynamic capability & 1 \\
\hline 4c model & 2 \\
\hline Entrepreneurial orientation & 1 \\
\hline Paradox theory & 1 \\
\hline Upper echelon theory & 1 \\
\hline Absorptive capacity & 1 \\
\hline Attention-based view & 1 \\
\hline Governance structure & 1 \\
\hline Social identity theory & 1 \\
\hline
\end{tabular}

